Provided for non-commercial research and education use. Not for reproduction, distribution or commercial use.

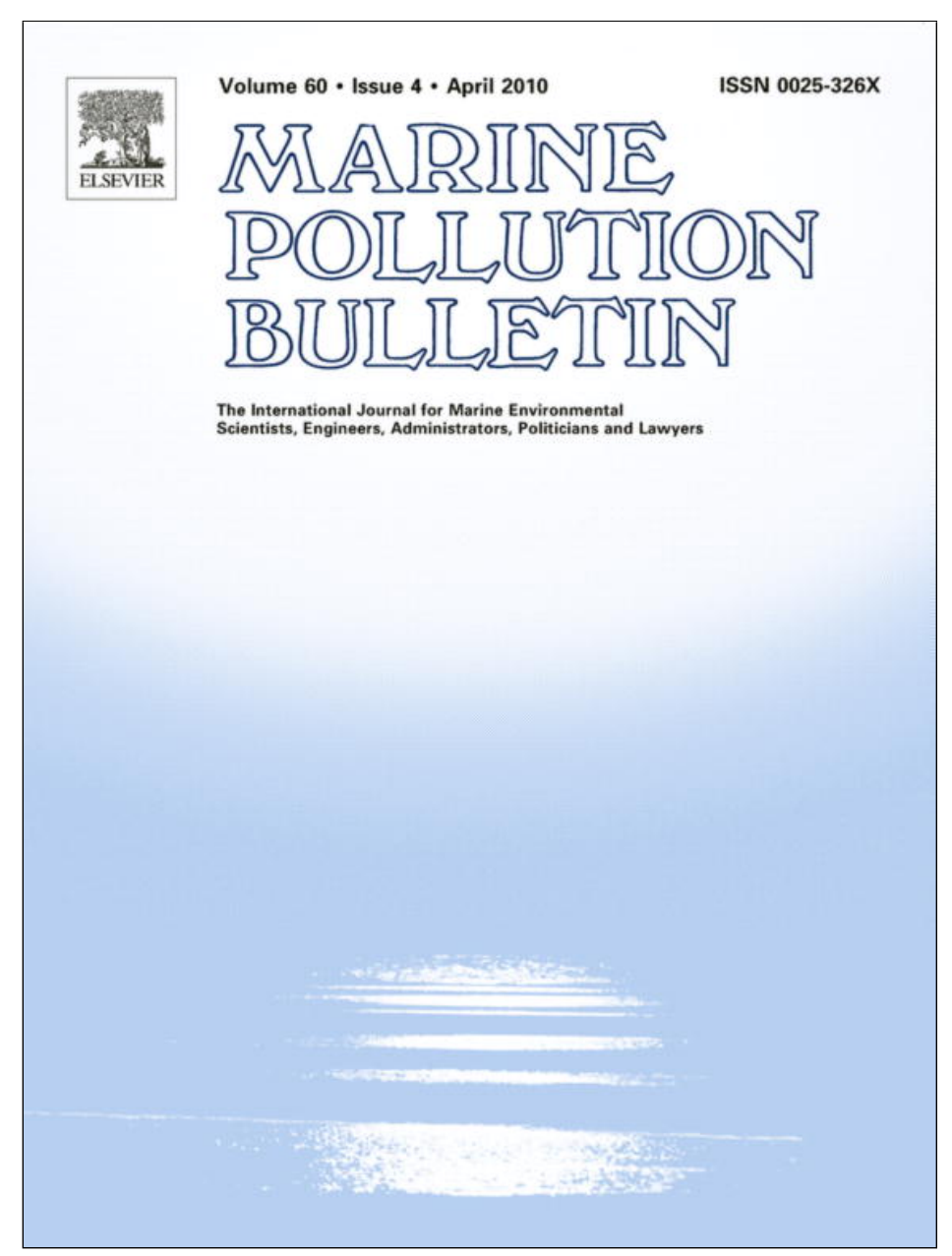

This article appeared in a journal published by Elsevier. The attached copy is furnished to the author for internal non-commercial research and education use, including for instruction at the authors institution and sharing with colleagues.

Other uses, including reproduction and distribution, or selling or licensing copies, or posting to personal, institutional or third party websites are prohibited.

In most cases authors are permitted to post their version of the article (e.g. in Word or Tex form) to their personal website or institutional repository. Authors requiring further information regarding Elsevier's archiving and manuscript policies are encouraged to visit:

http://www.elsevier.com/copyright 


\title{
The role of biogenic structures on the biogeochemical functioning of mangrove constructed wetlands sediments - A mesocosm approach
}

\author{
Gil Penha-Lopes ${ }^{\mathrm{a}, \mathrm{b}, *}$, Erik Kristensen $^{\mathrm{c}}$, Mogens Flindt ${ }^{\mathrm{c}}$, Perrine Mangion ${ }^{\mathrm{b}}$, Steven Bouillon ${ }^{\mathrm{d}}$, José Paula ${ }^{\mathrm{a}}$ \\ ${ }^{a}$ Centro de Oceanografia, Laboratório Marítimo da Guia, Faculdade de Ciências da Universidade de Lisboa, Avenida Na Senhora do Cabo, 939, 2750-374 Cascais, Portugal \\ ${ }^{\mathrm{b}}$ Institute of Biology, University of Southern Denmark, DK-5230 Odense M, Denmark \\ ${ }^{\mathrm{c}}$ Department of Analytical and Environmental Chemistry, Vrije Universiteit Brussel, Brussels, Belgium \\ ${ }^{\mathrm{d}}$ Katholieke Universiteit Leuven, Dept. of Earth and Environenmental Sciences, Kasteelpark Arenberg 20, B-3001 Leuven, Belgium
}

\section{A R T I C L E I N F O}

\section{Keywords:}

Carbon mineralization

Microbial pathways

Constructed wetlands

Mangrove

Domestic sewage

Biogenic structures

\begin{abstract}
A B S T R A C T
Benthic metabolism (measured as $\mathrm{CO}_{2}$ production) and carbon oxidation pathways were evaluated in 4 mangrove mesocosms subjected daily to seawater or $60 \%$ sewage in the absence or presence of mangrove trees and biogenic structures (pneumatophores and crab burrows). Total $\mathrm{CO}_{2}$ emission from darkened sediments devoid of biogenic structures at pristine conditions was comparable during inundation (immersion) and air exposure (emersion), although increased 2-7 times in sewage contaminated mesocosms. Biogenic structures increased low tide carbon gas emissions at contaminated (30\%) and particularly pristine conditions (60\%). When sewage was loaded into the mesocosms under unvegetated and planted conditions, iron reduction was substituted by sulfate reduction and contribution of aerobic respiration to total metabolism remained above 50\%. Our results clearly show impacts of sewage on the partitioning of electron acceptors in mangrove sediment and confirm the importance of biogenic structures for biogeochemical functioning but also on greenhouse gases emission.
\end{abstract}

(C) 2009 Elsevier Ltd. All rights reserved.

\section{Introduction}

Mangrove forests represent a productive ecosystem that plays a key role for carbon and nutrient cycling along many tropical coasts (Duarte et al., 2005; Kristensen et al., 2008a). They are sources or sinks of atmospheric $\mathrm{CO}_{2}$ depending on the balance of primary production, accretion and permanent storage of organic matter (OM) in sediments, OM exported by tides or consumed by both terrestrial and marine species, as well as carbon mineralization in sediments and creek waters (Bouillon et al., 2008a; Kristensen et al., 2008a; Nagelkerken et al., 2008).

Carbon oxidation in sediments is controlled by the availability of labile OM and electron acceptors (Canfield et al., 2005). Aerobic respiration and anaerobic sulfate reduction (SR) are usually the major decomposition pathways in mangrove sediments, while manganese and iron respiration, denitrification and methanogenesis have traditionally been considered unimportant (Kristensen et al., 2008a; Alongi, 2009). Low oxygen penetration into reactive marine sediments typically favours high importance of SR (Canfield et al., 2005), but other anaerobic processes may

\footnotetext{
* Corresponding author. Address: Centro de Oceanografia, Laboratório Marítimo da Guia, Faculdade de Ciências da Universidade de Lisboa, Avenida Na Senhora do Cabo, 939, 2750-374 Cascais, Portugal. Tel.: +351 214869211.

E-mail address: gil.penha-lopes@fc.ul.pt (G. Penha-Lopes).
}

predominate in mangrove environments depending on factors such as sediment grain size, tidal inundation, forest type, organic content, and bioturbation intensity (Kristensen, 2000; Alongi, 2009).

Benthic dwelling invertebrates as well as flora are known to disturb the top-sediment and several species create important physical structures (also known as biogenic structures) that influence significantly the sediment biogeochemistry (Kristensen et al., 2005). On a global scale, faunal ecosystem engineering affects the top $9 \mathrm{~cm}$ of sediment layer (Boudreau, 1998), while flora roots are known to affect sediment dynamic much deeper $(>30 \mathrm{~cm})$ in the sediment (Alongi, 2005). The burrowing, feeding, irrigation, construction and locomotory activities of benthic invertebrates and root development and functioning have significant implications for the physicochemical environment, and consequently to microorganism diversity, biomass and activity (Kristensen, 2000; Alongi, 2005; Canfield et al., 2005; Kristensen et al., 2005).

Mangrove sediments are characterized by an abundance of biogenic structures, such as tree pneumatophores and infauna burrows. These structures change the biogeochemical balance and increase the exchange of gases and solutes several fold, making them important conduits that influence carbon dynamics in mangrove forest (Holmer et al., 1999; Kitaya et al., 2002; Kristensen et al., 2008b). Pneumatophores have open lenticels during emersion, allowing rapid diffusion of gases into (e.g., $\mathrm{O}_{2}$ ) and from 
(e.g., $\mathrm{CO}_{2}$ and $\mathrm{CH}_{4}$ ) deep sediments via the air-filled aerenchyma tissue to the atmosphere (Purnobasuki and Suzuki, 2004, 2005), but can also stimulate SR through root exudates (Alongi, 1998; Kristensen and Alongi, 2006). Infaunal burrows, on the other hand, enhance the exchange of gases and nutrients through increasing the area of sediment and air/water interfaces as well as transport of labile detritus to subsurface layer during bioturbation activities (Kristensen, 1988; Kristensen 2008; Kristensen et al., 2008b).

This way biogenic structures may increase the importance of aerobic and suboxic, such as Fe reduction (Nielsen et al., 2003; Kristensen and Alongi, 2006) and denitrification (Hansen and Kristensen, 1998; Heilskov and Holmer, 2001; Purvaja et al., 2004) pathways for carbon mineralization in subsurface sediments at the same time that fuel anaerobic carbon degradation deep in the sediment (Kristensen, 2000; Ferreira et al., 2007). Also, both denitrifying bacteria (Corredor and Morell, 1994; Rivera-Monroy and Twilley, 1996) and methanogens (Purvaja and Ramesh, 2001; Hegde et al., 2003; Alongi et al., 2005) can increase significantly their activity at high nutrient and organic loading, coexisting with highly productive sulfate reducers (Holmer and Kristensen, 1994b; Lyimo et al., 2002).

The use of wetlands for processing nutrient and organic-rich wastewater has proved effective to prevent coastal pollution in developing countries (Crites et al., 2006). However, possible harmful effects due to toxic materials and pathogens in wastewater (AlSayed et al., 2005) and anthropogenic degradation of natural wetlands have forced managers to use constructed wetlands (Kivaisi, 2001). In many cases constructed mangrove wetlands have proven to be efficient in nutrient filtration (Wu et al., 2008b; Yang et al., 2008), with high survival and growth rates of mangrove flora (Wong et al., 1997b; Yang et al., 2008) and associated macrofauna (Penha-Lopes et al., 2009; Penha-Lopes et al., in press). However, a continuous loading of organic-rich wastewater at a level above the system capacity usually leads to severely reduced $\mathrm{O}_{2}$ penetration (Gray et al., 2002) and OM accumulation in sediments (Holmer and Kristensen, 1994a, b Valdemarsen et al., 2009) which may induce negative effects on sediment associated flora and fauna due to stimulated SR and toxic sulfide accumulation (Hargrave et al., 2008). Studies on nutrient filtration efficiency of constructed wetlands for wastewater treatment have so far only focused on the behaviour of plants and/or microorganisms (Wong et al., 1995; Stottmeister et al., 2003; Wu et al., 2008a), while macrofauna and associated biogeochemical functioning have been ignored.

Knowledge on the ecological response of mangrove sediments to urban sewage emissions is urgently needed and this study aims to improve the understanding of direct and indirect effects of severe sewage contamination. This manuscript focuses on carbon gas (i.e. $\mathrm{CO}_{2}$ and $\mathrm{CH}_{4}$ ) emissions under immersion and emersion periods, with special emphasis on the importance of biogenic structures (pneumatophores and crab burrows), as well on the most important carbon oxidation pathways used. Study the biogenic structure functioning is important to fully comprehend the effects of organic discharge on mangrove forests and to provide basic knowledge for future development of sustainable mangrove wastewater wetlands. We also provide rough net budgets of carbon gas emission in constructed mangrove wetlands under sewage contamination and different vegetation treatments and discuss the long-term implications for the ecosystem functioning and health.

\section{Materials and methods}

\subsection{Experimental setup}

A mesocosm system consisting of 4 cells ( $9 \mathrm{~m}^{2}$ each) was constructed at the upper Avicennia marina (Forsk.) belt of the Jangwani mangrove forest near Dar es Salaam, Tanzania (Penha-Lopes et al., 2009). The 4 cells were divided according to "vegetation" treatment, with 2 unvegetated cells and 2 cells planted with $A$. marina saplings. Sediment was laid and saplings planted (at a density of $2.8 \mathrm{~m}^{-2}$ ) on selected plots in early February 2006. The system was initially inundated exclusively with seawater and secondary sewage loading was initiated in early October 2006. One replicate was assigned per sewage loading for each vegetation treatment. Secondary sewage was mixed with natural seawater to obtain loadings of $60 \%$. A diurnal tidal rhythm was simulated with $12 \mathrm{~h}$ immersion to $0.1 \mathrm{~m}$ depth starting at 23:00. The basic chemical characteristics of sewage-seawater mixtures during the first 6 months (average monthly sampling) are presented in Table 1. All other measurements are given for the period March-April of 2007 (6 month campaign) period except for sediment total carbon and nitrogen that are presented for October 2006 and April 2007. A. marina trees were $50.3 \pm 1.2 \mathrm{~cm}( \pm \mathrm{SE})$ tall and litter fall from the young trees was absent when sewage discharge was initiated. They grew to $107.8 \pm 7.8 \mathrm{~cm}$ with litter fall of $1.17 \pm 0.20 \mathrm{~g} \mathrm{~m}^{-2}$ day $^{-1}$ in April 2007 (PUMPSEA, 2008).

\subsection{Epifauna and biogenic structures}

Mangrove epifauna was introduced to each cell in August 2006. Two of the most abundant crab species found in Indo-Pacific mangrove forests, Uca annulipes ( $\mathrm{H}$. Milne Edwards, 1837) and U. inversa (Hoffmann, 1874) populated the mesocosms (approximately

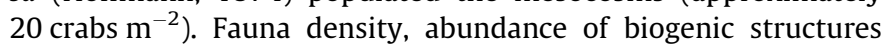
(pneumatophores and burrows) and burrow morphology at the time of the present measurements (March and April 2007) were obtained (Table 2) from parallel studies (PUMPSEA, 2008; PenhaLopes et al., 2009). Although other macro (e.g., gastropods, polychaetes and oligochaetes) and meiofauna were registered at the mesocosms, no differences on biomass and diversity were found between mesocosms at different sewage concentrations and vegetated conditions (Penha-Lopes et al., in press).

\subsection{Sediment properties}

Triplicate sediment cores $(5 \mathrm{~cm}$ i.d.) from each mesocosm cell were sliced into $0-2,4-6$, and $8-10 \mathrm{~cm}$ depth intervals and analyzed for organic content (loss on ignition, LOI) in March 2007. Simultaneously, 9 cores for determination of sediment density and water content was sliced into $0-1,1-2,2-3,3-4,4-6,8-10$, and $12-14 \mathrm{~cm}$ depth intervals. Water content was determined from water loss upon drying of sediment subsamples at $100^{\circ} \mathrm{C}$ for $24 \mathrm{~h}$. Wet density was measured as the weight of a known sediment volume. Water content and density is presented as average porosity of all examined cells due to limited variability. Organic content was determined as weight loss of dried sediment after combustion for $6 \mathrm{~h}$ at $520^{\circ} \mathrm{C}$. Chlorophyll-a (Chl a) content was analyzed only in the surface sediment $(0-2 \mathrm{~cm})$ by the standard spectrophotometric method (Lorenzen, 1967).

Solid phase Fe was determined for the same cells in a previous study (Penha-Lopes et al., 2009).

\subsection{Sulfate reduction assay}

Rates of sulfate reduction were measured by the core injection technique of Jørgensen (1978). Three 16-cm-long sediment cores were retrieved from each mesocosm cell using $20-\mathrm{cm}$ long and $2.6-\mathrm{cm}$ i.d. core tubes with silicone-filled injection ports. Carrierfree ${ }^{35} \mathrm{~S}_{-} \mathrm{SO}_{4}^{2-}$ was injected at $1-\mathrm{cm}$ intervals to $13 \mathrm{~cm}$ depth, and the cores were incubated at $25^{\circ} \mathrm{C}$ with dry surface in darkness for 4-6 h. Subsequently, each core was sliced at 2-cm intervals and fixed in $20 \%$ zinc acetate. Samples were stored frozen until dis- 
Table 1

Average chemical characteristics of the sewage-sea water mixtures used in the experimental mesocosms from November 2006 to March 2007 ( 5 months), with 3 samples per mesocosm and 3 system replicates per treatment $(N=45)$. (DO: dissolved oxygen). Values are given as averages \pm SE (adapted from PUMPSEA (2008)).

\begin{tabular}{|c|c|c|c|c|c|c|}
\hline Sewage loading (\%) & Salinity $(\% o)$ & $\mathrm{DO}_{\text {day }}(\mu \mathrm{M})$ & $\mathrm{DO}_{\text {night }}(\mu \mathrm{M})$ & $\mathrm{NH}_{4}^{+}(\mu \mathrm{M})$ & $\mathrm{NO}_{3}^{-}(\mu \mathrm{M})$ & $\mathrm{PO}_{4}^{3-}(\mu \mathrm{M})$ \\
\hline 0 & $39.1 \pm 0.6$ & $308 \pm 133$ & $197 \pm 17$ & $26 \pm 2$ & $3.6 \pm 1.4$ & $42 \pm 4$ \\
\hline 60 & $18.9 \pm 1.4$ & $225 \pm 256$ & $9 \pm 1$ & $194 \pm 17$ & $5.0 \pm 1.4$ & $206 \pm 14$ \\
\hline
\end{tabular}

Table 2

Abundance of fiddler crabs, gastropods and pneumatophores in mesocosm cells with and without vegetation and sewage treatment at March and April 2007. Burrow volume and wall surface area data are from (Penha-Lopes et al. (2009). Values are given as mean \pm SE $(n=3)$; n.a.: not applicable.

\begin{tabular}{|c|c|c|c|c|c|c|c|}
\hline Vegetation & $\begin{array}{l}\text { Sewage } \\
(\%)\end{array}$ & $\begin{array}{l}\text { Crab density } \\
\left(\mathrm{m}^{-2}\right)\end{array}$ & $\begin{array}{l}\text { Burrow density } \\
\left(\mathrm{m}^{-2}\right)\end{array}$ & $\begin{array}{l}\text { Gastropod density } \\
\left(\mathrm{m}^{-2}\right)\end{array}$ & $\begin{array}{l}\text { Pneumatophore density } \\
\left(\mathrm{m}^{-2}\right)\end{array}$ & $\begin{array}{l}\text { Burrow volume } \\
\left(\mathrm{cm}^{-3}\right)\end{array}$ & $\begin{array}{l}\text { Burrow wall surface area } \\
\left(\mathrm{cm}^{-2}\right)\end{array}$ \\
\hline \multirow[t]{2}{*}{ Unvegetated } & 0 & $12 \pm 1$ & $16 \pm 1$ & $4 \pm 0$ & n.a. & $37.91 \pm 4.14$ & $27.48 \pm 2.17$ \\
\hline & 60 & $11 \pm 3$ & $14 \pm 4$ & $4 \pm 0$ & n.a. & $41.57 \pm 9.55$ & $28.04 \pm 4.47$ \\
\hline \multirow[t]{2}{*}{ Vegetated } & 0 & $16 \pm 1$ & $21 \pm 1$ & $4 \pm 0$ & $15 \pm 1$ & $34.74 \pm 2.33$ & $22.73 \pm 3.27$ \\
\hline & 60 & $10 \pm 2$ & $13 \pm 3$ & $4 \pm 0$ & $25 \pm 2$ & $47.52 \pm 6.57$ & $28.97 \pm 2.92$ \\
\hline
\end{tabular}

tillation by the one step total reduced sulfide extraction described in Fossing and Jørgensen (1989). The ${ }^{35} \mathrm{~S}$ activity in sediment and distillate was determined by liquid scintillation analysis, and sulfate reduction rates were determined from the relative activity of ${ }^{35} \mathrm{~S}$ recovered in the distillate.

\subsection{Anoxic sediment incubations}

The vertical distribution of total anaerobic microbial $\mathrm{CO}_{2}$ production (TACP) and respiratory $\mathrm{Fe}(\mathrm{III})$ reduction was determined in sediment from all treatments. Three sediment cores $(8 \mathrm{~cm}$ i.d.) were sliced into $0-2,2-4,8-10$, and $12-14 \mathrm{~cm}$ depth intervals. Sediment from each depth was rapidly homogenized and transferred into 8 glass scintillation vials (jars), which were capped with no headspace, taped to prevent oxygen intrusion and incubated in the dark at $28{ }^{\circ} \mathrm{C}$. Over a month, every week two vials from each depth were sacrificed for determination of changes in dissolved $\mathrm{CO}_{2}$ and reactive Fe pools. Sediment was transferred to double centrifuge tubes and porewater was obtained by centrifugation (10 min, $1500 \mathrm{rpm}$ ). Samples for $\mathrm{CO}_{2}$ were preserved with $\mathrm{HgCl}_{2}$ and analyzed as soon as possible using the flow injection/diffusion cell technique of Hall and Aller (1992). Furthermore, solid phase particulate iron pools were determined on jar sediment as described above. Reaction rates in jars were calculated as the slope of the linear fit of concentration versus time.

\subsection{Denitrification assay}

Rates of denitrification during immersion were measured in February 2007 using the ${ }^{15} \mathrm{~N}$ isotope pairing technique on intact sediment cores (Nielsen, 1992). Ten undisturbed sediment cores from each cell were adjusted to $\sim 10 \mathrm{~cm}$ height and placed in groups of 5 into 2 tanks. After stabilization overnight, one tank was exposed to light and the other was kept in darkness. The denitrification assay was initiated by amending the water of each tank with ${ }^{15} \mathrm{NO}_{3}^{-}\left(99.2 \%{ }^{15} \mathrm{~N}\right.$, Sigma-Aldrich) to a final concentration of $\sim 60 \mu \mathrm{M}$. The water above the cores was mixed manually to ensure homogeneous distribution of tracer. About 15 min later, the core tubes were sealed gas-tight either with rubber stoppers or transparent lids for dark and light incubations, respectively. After incubation for $3-5 \mathrm{~h}\left(\mathrm{O}_{2}\right.$ did not change more than $20 \%$ from air saturation), sediment and water column in each core were mixed completely with a PVC rod. Duplicate $20 \mathrm{ml}$ samples of the resulting slurry were transferred to gas-tight vials ( $12 \mathrm{ml}$ Extainers, Labco), preserved with formaldehyde $(100 \mu \mathrm{L}, 38 \%)$ and sealed ensuring no entrapped air. ${ }^{15} \mathrm{~N}$ content of the $\mathrm{N}_{2}$ gas was analyzed on a Flash 1112 Series Elemental Analyser (EA) coupled via a Conflo III to a ThermoScientific Delta+ XL following the methodology described in Trimmer et al. (2006). Denitrification rates were calculated from ${ }^{29} \mathrm{~N}_{2}$ and ${ }^{30} \mathrm{~N}_{2}$ production rates as described by Nielsen (1992).

\section{7. $\mathrm{CO}_{2}$ and $\mathrm{CH}_{4}$ exchange across the sediment-water/air interface}

Exchange of carbon gases across the sediment-water interface $\left(\mathrm{TCO}_{2}\right)$ and over air-exposed bare (without biogenic structures) sediments $\left(\mathrm{TCO}_{2}\right.$ and $\left.\mathrm{CH}_{4}\right)$ were determined in mesocosm cells following the techniques described in detailed by Kristensen et al. (2008b). Three of the cores were left exposed to sunlight to determine net primary production (NPP) and three cores were darkened with aluminium foil to determine respiration (RSP) at pristine and contaminated sediment at both planted and unplanted conditions. The $\mathrm{CO}_{2}$ fluxes were also determined in deployments on exposed sediments (emersion) with one crab burrow and sediment with 3 pneumatophores of A. marina. Occasionally, sediment-air methane emissions were tested simultaneously with the in situ $\mathrm{CO}_{2}$ exchange measurements in selected mesocosms. In this study we designate the carbon release from sediment at emersion periods as $\mathrm{CO}_{2}$, while wet flux and jar accumulation of dissolved inorganic carbon is considered as $\mathrm{TCO}_{2}$ and TACP, respectively.

\subsection{Epifauna respiration}

The respiratory $\mathrm{CO}_{2}$ release by fiddler crabs (both Uca species) and gastropods were determined from laboratory incubations at in situ temperature using the Li-6400 equipment and technique described in Kristensen et al. (2008b). A group of 30 different sized (0.4-8 g wet weight) fiddler crabs of each species and sex, and 30 gastropods (2-45 g wet weight) were caught randomly at the Kunduchi mangrove forest and immediately brought to the laboratory.

\subsection{Statistical analysis}

Gas fluxes were tested using 2-way ANOVA, except for denitrification where a 3-way ANOVA was used. When relevant, the ANOVA's were followed by a Bonferroni test or SNK to find differences between treatments. A significance level of $\alpha=0.05$ was used in all ANOVA tests, unless otherwise stated. 
Table 3

Sediment carbon and nitrogen composition and $\mathrm{C} / \mathrm{N}$ ratio at the beginning $(0)$ and 6 month campaign (6) and different vegetation (Bare and A. Marina) and sewage (0 and $60 \%)$ conditions. Values are given as averages \pm SE $(n=3)$.

\begin{tabular}{|c|c|c|c|c|}
\hline & \multicolumn{2}{|l|}{$0 \%$} & \multicolumn{2}{|l|}{$60 \%$} \\
\hline & Bare & A. marina & Bare & A. marina \\
\hline \multicolumn{5}{|c|}{ TOC (\%) } \\
\hline 0 & $0.305 \pm 0.166$ & $0.305 \pm 0.166$ & $0.305 \pm 0.166$ & $0.305 \pm 0.166$ \\
\hline 6 & $0.236 \pm 0.015$ & $0.204 \pm 0.034$ & $0.312 \pm 0.034$ & $0.339 \pm 0.003$ \\
\hline \multicolumn{5}{|c|}{ TN (\%) } \\
\hline 0 & $0.033 \pm 0.014$ & $0.033 \pm 0.014$ & $0.033 \pm 0.014$ & $0.033 \pm 0.014$ \\
\hline 6 & $0.026 \pm 0.004$ & $0.023 \pm 0.009$ & $0.039 \pm 0.005$ & $0.038 \pm 0.003$ \\
\hline \multicolumn{5}{|c|}{$\mathrm{C} / \mathrm{N}(\mathrm{mol} / \mathrm{mol})$} \\
\hline 0 & $10.3 \pm 1.3$ & $10.3 \pm 1.3$ & $10.3 \pm 1.3$ & $10.3 \pm 1.3$ \\
\hline 6 & $10.8 \pm 1.0$ & $10.8 \pm 2.4$ & $9.4 \pm 0.1$ & $10.5 \pm 1.0$ \\
\hline
\end{tabular}

\section{Results}

\subsection{Water and sediment characteristics}

Nutrient concentrations increased with sewage loading, while salinity and dissolved oxygen decreased (Table 1 ). The daily variation in top-sediment temperature was similar in all treatments.
The temperature was constant at around $27^{\circ} \mathrm{C}$ at night and increased at dawn (7:00) to reach a maximum of $\sim 37^{\circ} \mathrm{C}$ at noon (13:00) followed by a slow but gradual decrease back to the night time level. In all cells porosity ranged from 0.35 to 0.47 , except for high porosity of 0.66 in the $12-14 \mathrm{~cm}$ depth interval. Organic content was constant with depth in the upper $10 \mathrm{~cm}$ of the sediment in all treatments and ranged from 0.9 to $1.9 \%$. Sediment TOC and TN (Table 3) showed a striking difference at the beginning and end of the experiment, with a decrease of nearly $30 \%$ at pristine conditions and an increase of $10 \%$ when sediment was subjected to sewage discharge. Nevertheless, the $\mathrm{C} / \mathrm{N}$ ratios remained similar with large variability. In non-contaminated cells Chlorophyll-a concentration in the top-sediment was $13.9 \pm 3.9 \mu \mathrm{g} \mathrm{g}^{-1}$ in unveg-

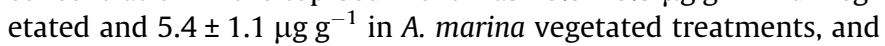
in the $60 \%$ sewage treated cells the corresponding values were $23.1 \pm 9.4$ and $14.0 \pm 3.5 \mu \mathrm{g} \mathrm{g}^{-1}$, respectively, increasing then with sewage dosing and decreasing with vegetation cover.

Solid phase iron profiles differed among treatments (Fig. 1). Total iron differed according to vegetation, and when integrated to $14 \mathrm{~cm}$ depth total iron was $\sim 250$ and $100-140 \mu \mathrm{mol} \mathrm{cm}^{-3}$ in vegetated and non-vegetated sediment, respectively, irrespective of contamination level. $\mathrm{Fe}(\mathrm{II})$ always dominated in contaminated cells occasionally exceeding $20 \mu \mathrm{mol} \mathrm{cm}{ }^{-3}$, decreasing with depth at

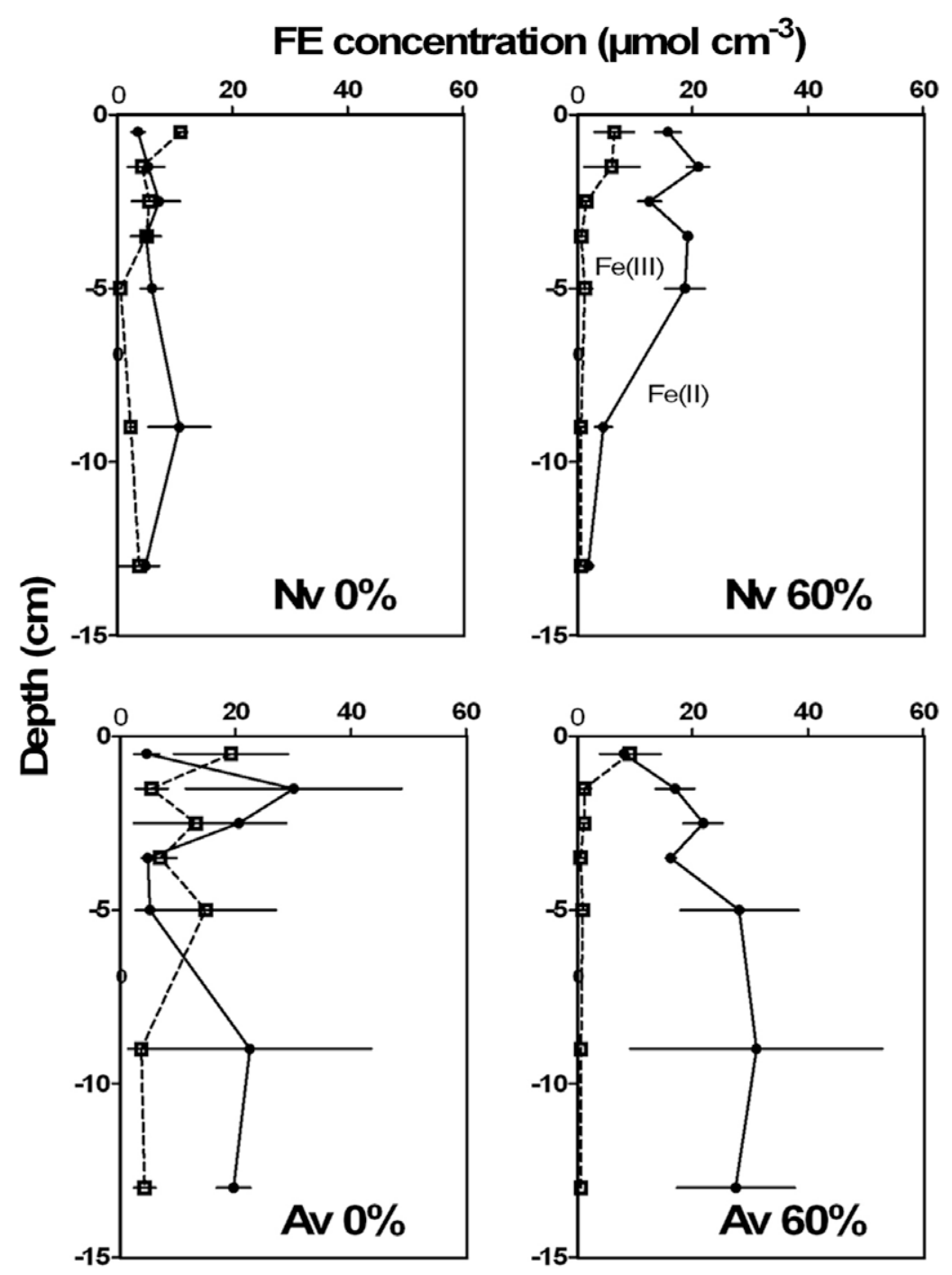

Fig. 1. Vertical profiles of solid phase iron under both vegetation (A. marina vegetated (Av) and non-vegetated (Nv)) and sewage loading conditions during March 2007. Values are given as mean \pm range $(n=2)$. 

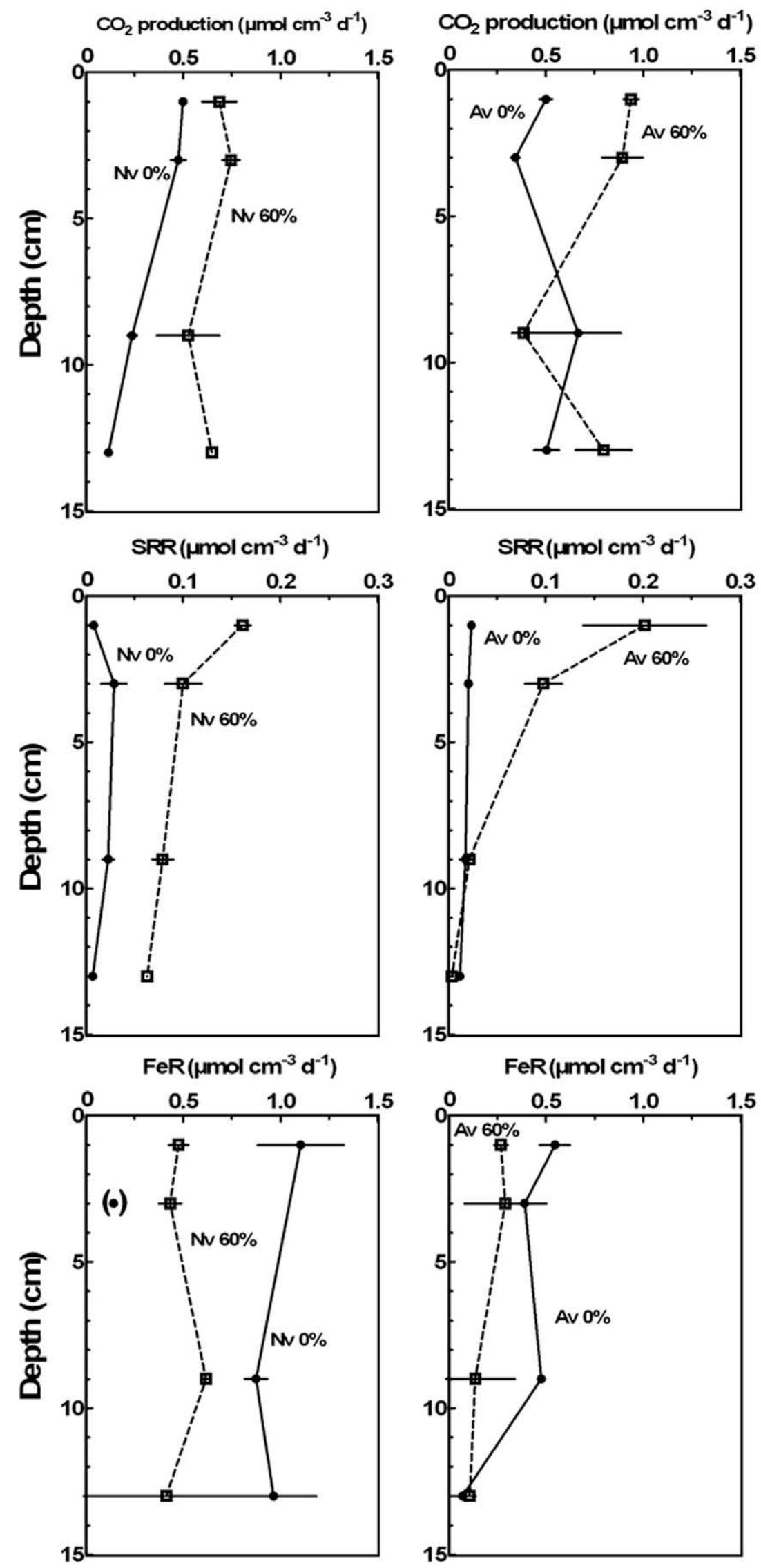

Fig. 2. Vertical profiles of anaerobic $\mathrm{CO}_{2}$ production (upper); sulfate reduction (SRR, mid); and iron reduction (FeR, lower) in 0 and $60 \%$ sewage treated sediments during March-April 2007 period. Results are shown for sediment from A. marina vegetated (Av) and non-vegetated (Nv) cells. Values are given as mean \pm SE $(n=3)$. ( $)$ indicates an outlier. 
unvegetated but remained constant below $5 \mathrm{~cm}$ at planted treatments, while $\mathrm{Fe}(\mathrm{III})$ never exceeded $10 \mu \mathrm{mol} \mathrm{cm}{ }^{-3}$ and was almost absent below $2 \mathrm{~cm}$ depth irrespective of vegetation. In non-contaminated cells, however, the distribution of $\mathrm{Fe}(\mathrm{II})$ and $\mathrm{Fe}(\mathrm{III})$ appeared constant with depth, and a much higher importance of $\mathrm{Fe}(\mathrm{III})$ was observed (depth integrated $\mathrm{Fe}$ (III) was on average 90 and $40 \mu \mathrm{mol} \mathrm{cm}^{-3}$ non-vegetated and vegetated cells, respectively).

\subsection{Carbon mineralization pathways}

Anaerobic respiration processes, sulfate reduction (SRR) and iron reduction (FeR), were determined independently and total anaerobic $\mathrm{CO}_{2}$ production (TACP) and FeR was assessed from the same jar incubations. TACP was clearly affected by sewage amendment (Fig. 2 - upper). TACP ranged from 117-667 $\mathrm{nmol} \mathrm{cm}^{-3} \mathrm{~d}^{-1}$ in non-contaminated sediment and was $386-939 \mathrm{nmol} \mathrm{cm}^{-3} \mathrm{~d}^{-1}$ in contaminated sediment. On average sewage amendment increased TACP by $58-330 \%$ in unvegetated sediment, mainly in the $12-14 \mathrm{~cm}$ depth interval, while the corresponding TACP enhancement of $87-150 \%$ in vegetated sediment was primarily observed in the uppermost sediment layers $(1-2 \mathrm{~cm})$.

SRR also showed a clear and significant response to sewage loading, mainly in the upper $5 \mathrm{~cm}$ of the sediment (Fig. 2 - mid). SRR was $<30 \mathrm{nmol} \mathrm{cm}^{-3} \mathrm{~d}^{-1}$ in non-contaminated sediments, but was generally stimulated to $>>100 \mathrm{nmol} \mathrm{cm}^{-3} \mathrm{~d}^{-1}$ in the top $4 \mathrm{~cm}$ of contaminated sediments. Below $4 \mathrm{~cm}$ depth, SRR resembled noncontaminated sediment ( $25 \mathrm{nmol} \mathrm{cm}{ }^{-3} \mathrm{~d}^{-1}$, vegetated cells) or was significantly higher $\left(>75 \mathrm{nmol} \mathrm{cm}{ }^{-3} \mathrm{~d}^{-1}\right.$, non-vegetated cells).

The trend was opposite for FeR (Fig. 2 - lower) where non-contaminated sediments showed highest rates of FeR in the upper $10 \mathrm{~cm}\left(0.8\right.$ and $0.45 \mu \mathrm{mol} \mathrm{cm}{ }^{-3} \mathrm{~d}^{-1}$ in unvegetated and vegetated sediment), roughly twice as high as FeR in the corresponding contaminated sediment ( 0.5 and 0.2 in unvegetated and vegetated sediment). Below $10 \mathrm{~cm}$ depth FeR rates were similar in all treatments. The very low value at $3 \mathrm{~cm}$ depth in contaminated unvegetated sediment is considered an outlier. Overall, the presence of trees appeared to decrease FeR in both non-contaminated (up to $92 \%$ ) and contaminated treatments (by $32-75 \%$ ).

Denitrification was strongly affected by the interaction of vegetation, sewage and light exposure $(p<0.001)$. In contaminated sediments denitrification rates in the dark (400-550 $\mu \mathrm{mol} \mathrm{N} \mathrm{m}^{-2} \mathrm{~d}^{-1}$ ) were stimulated nearly 10 times when compared to non-contaminated sediments $\left(30-50 \mu \mathrm{mol} \mathrm{N} \mathrm{m} \mathrm{m}^{-2} \mathrm{~d}^{-1}\right)$, for non-vegetated and vegetated sediments, respectively (Fig. 3 ). Light exposure positively stimulated denitrification in all treatments, leading to denitrification rates of $\sim 2800$ and $1900 \mu \mathrm{mol} \mathrm{N} \mathrm{m}^{-2} \mathrm{~d}^{-1}$ in non-

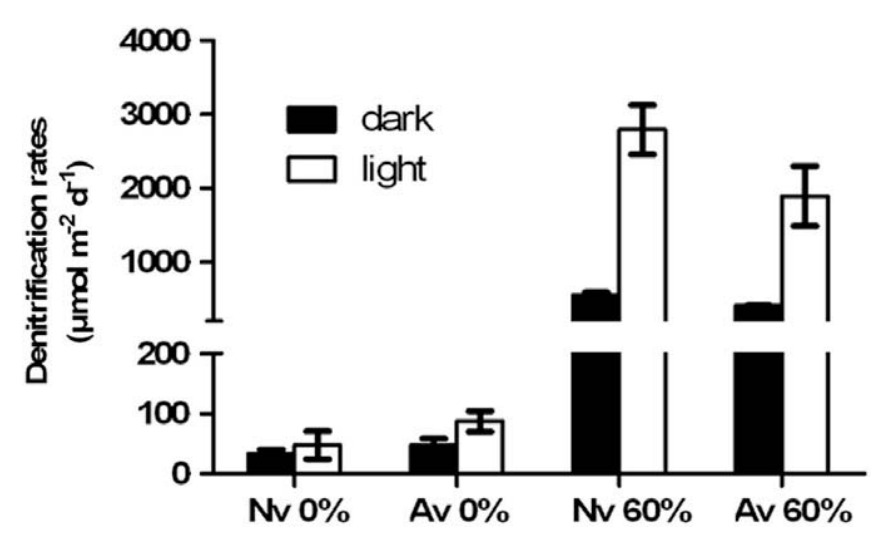

Fig. 3. Denitrification by the sediment in 0 and $60 \%$ treatments with different vegetation types ( $\mathrm{Av}-\mathrm{A}$. marina; B - non-vegetated) during March 2007. Rates are given for light and dark conditions. Values are given as mean $\pm \operatorname{SE}(n=2-3)$. vegetated and vegetated contaminated sediments, respectively. The corresponding rates in non-contaminated cells were more than one order of magnitude lower, and similar values were obtained between light and darkness and both vegetation conditions (ranging from 33 to $88 \mu \mathrm{mol} \mathrm{N} \mathrm{m}{ }^{-2} \mathrm{~d}^{-1}$ ).

Depth profiles of TACP was generally higher than the estimated sum of SRR, FeR and denitrification (assumed to occur only in the upper $2 \mathrm{~cm}$ ) when converted to carbon units $\left(\mathrm{SRR} \times 2=\mathrm{CO}_{2}\right.$ production; FeR $/ 4=\mathrm{CO}_{2}$ production; Den $=4 / 5 \mathrm{CO}_{2}$ ) (Table 5). TACP was $20-2000 \%$ higher than the sum of individual anaerobic processes, except for unvegetated non-contaminated sediment where TACP was 20 and 50\% lower at 8 and $14 \mathrm{~cm}$ depth, respectively. In any case, FeR was the most important measured contributor to TACP in non-contaminated sediments, while SRR dominated TACP in contaminated sediments.

\section{3. $\mathrm{CO}_{2}$ exchange across the sediment-water/air interface}

The sediment-water exchange of $\mathrm{TCO}_{2}$ was not influenced by plants but was significantly enhanced by sewage (Fig. 4 - upper). Sewage exposure increased the dark $\mathrm{TCO}_{2}$ efflux (respiration: RSP) by a factor of four $(p<0.05)$ from 25 to $104 \mathrm{mmol} \mathrm{m}^{-2} \mathrm{~d}^{-1}$ in non-vegetated cells and a factor of two (although statistically insignificant) from 33 to $62 \mathrm{mmol} \mathrm{m}^{-2} \mathrm{~d}^{-1}$ in vegetated cells. Benthic net primary production (NPP) during immersion was not influenced by the presence of plants, since $\mathrm{CO}_{2}$ uptake rate in the light ranged from 11 to $34 \mathrm{mmol} \mathrm{m}^{-2} \mathrm{~d}^{-1}$ under pristine conditions and increased significantly $(p<0.01)$ for contaminated sediments to $136-301 \mathrm{mmol} \mathrm{m}^{-2} \mathrm{~d}^{-1}$ in non-vegetated and vegetated cells, respectively. Gross primary production $(\mathrm{GPP}=\mathrm{RSP}-\mathrm{NPP})$ was similar in planted and unplanted mesocosm cells. However, under pristine conditions GPP ranged from 45 to $60 \mathrm{mmol} \mathrm{m}^{-2} \mathrm{~d}^{-1}$ while under 60\% sewage treatment the rates were 4.3-6.7 times higher $(p<0.05)$ for unvegetated and planted conditions, respectively.

$\mathrm{CO}_{2}$ emissions from exposed and darkened sediment to the atmosphere (RSP) were greatly increased $(p<0.05)$ by sewage exposure from 6-14 to $42-62 \mathrm{mmol} \mathrm{m}^{-2} \mathrm{~d}^{-1}$, while vegetation had no significant effect (Fig. 4 - lower). RSP was nearly 10 times higher in contaminated $\left(62 \pm 14 \mathrm{mmol} \mathrm{m}^{-2} \mathrm{~d}^{-1}\right)$ than non-contaminated $\left(6 \pm 1 \mathrm{mmol} \mathrm{m}^{-2} \mathrm{~d}^{-1}\right)$ cells for unvegetated mesocosms $(p<0.01)$. In vegetated cells $\mathrm{CO}_{2}$ emissions were not significantly stimulated by sewage amendment, although the average $\mathrm{CO}_{2}$ emission was $\sim 3$ times higher in contaminated cells (14 \pm 6 and $42 \pm$ $3 \mathrm{mmol} \mathrm{m}{ }^{-2} \mathrm{~d}^{-1}$ in non-contaminated and contaminated sediment, respectively). RSP of air-exposed sediment was similar in rates and pattern to that of inundated sediment. Benthic net primary production (NPP) in exposed non-contaminated sediment was similar regardless of vegetation $\left(\sim 0.5 \pm 1.5 \mathrm{mmol} \mathrm{m}^{-2} \mathrm{~d}^{-1}\right)$. NPP in nonvegetated contaminated sediment was significantly stimulated $(p<0.001)$ by sewage amendment and was $61 \pm 10 \mathrm{mmol} \mathrm{m}^{-2} \mathrm{~d}^{-1}$. However, in vegetated contaminated cells, a surprising light $\mathrm{CO}_{2}$ emission was observed $\left(3.9 \pm 1.4 \mathrm{mmol} \mathrm{m}^{-2} \mathrm{~d}^{-1}\right)$, which was only different $(p<0.001)$ from that measured in unvegetated $60 \%$ cells. Furthermore, in exposed sediment there was significant interaction between vegetation and sewage contamination $(p<0.001)$. Gross primary production was greatly enhanced $(p<0.05)$ in unvegetated contaminated cells $\left(\sim 123 \mathrm{mmol} \mathrm{m}^{-2} \mathrm{~d}^{-1}\right)$ when compared with the other treatments $\left(6-38 \mathrm{mmol} \mathrm{m}^{-2} \mathrm{~d}^{-1}\right)$.

$\mathrm{CH}_{4}$ emissions were generally 2-3 orders of magnitude lower than $\mathrm{CO}_{2}$ emissions. $\mathrm{CH}_{4}$ emission during emersion was similar in unvegetated and vegetated non-contaminated sediments (34.8-53.7 $\left.\mu \mathrm{mol} \mathrm{m}^{-2} \mathrm{~d}^{-1}\right)$ but increased significantly $(p<0.05) 8$ 10 times in contaminated sediments (Fig. 5). Furthermore, one test deployment showed dramatically increased $\mathrm{CH}_{4}$ emissions up to $6000 \mu \mathrm{mol} \mathrm{m}{ }^{-2} \mathrm{~d}^{-1}$ in sediments with biogenic structures (A. marina pneumatophores, $\sim 400 \mathrm{~m}^{-2}$ ). 


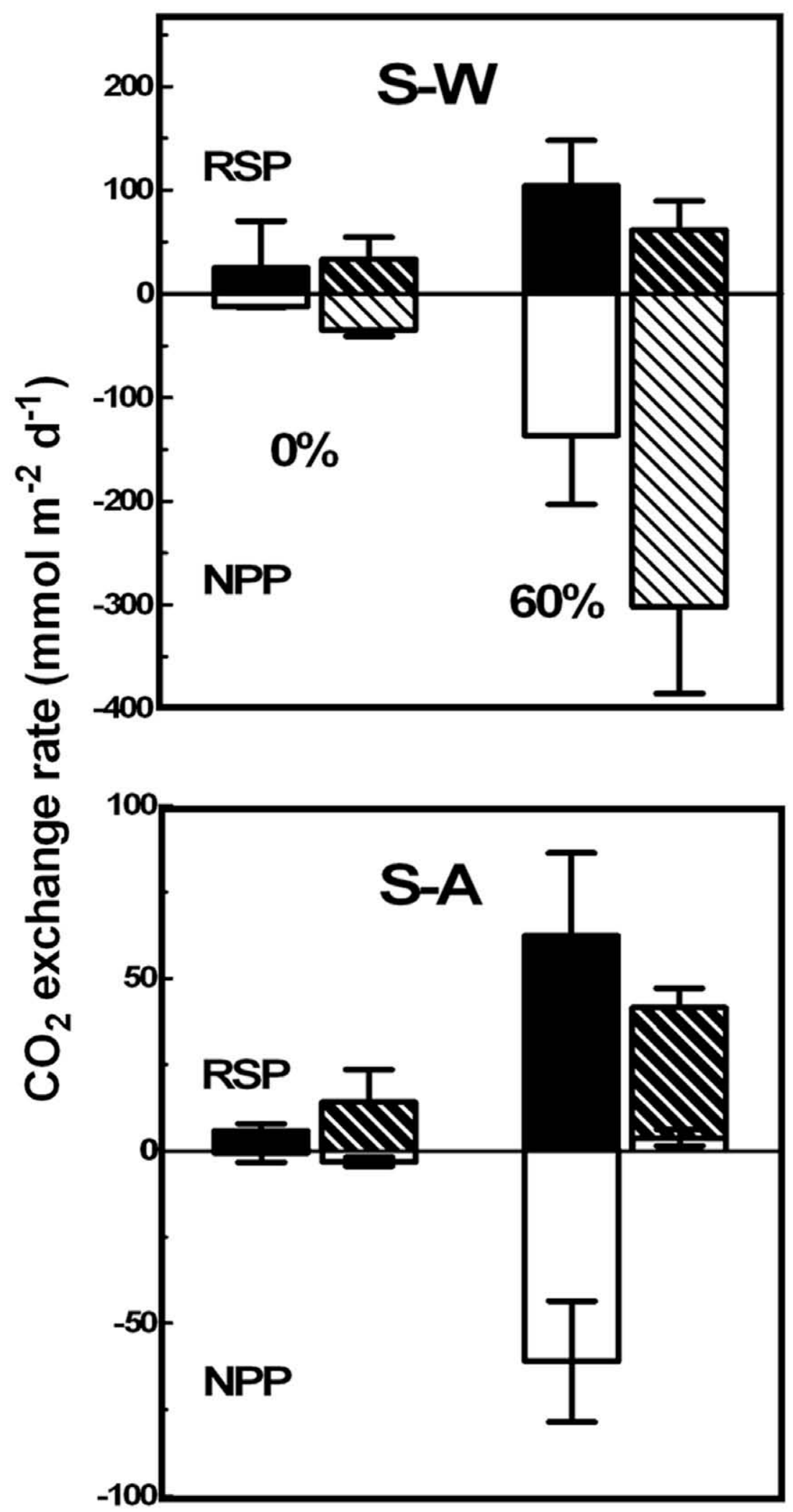

Fig. 4. Sediment-Water (S-W) and Sediment-Air (S-A) fluxes of $\mathrm{CO}_{2}$ in unvegetated (solid and open bars) and Avicennia marina vegetated (hatched bars) cells exposed to 0 and 60\% sewage loading in the dark (RSP - black background) and in light (NPP - white background) during March 2007. Notice the difference in scaling between upper and lower panels. Values are given as mean $\pm \mathrm{SE}(n=3)$.

3.4. $\mathrm{CO}_{2}$ emissions by pneumatophores, burrows, crabs and gastropods

Emission of $\mathrm{CO}_{2}$ was enhanced considerably by the presence of pneumatophores and burrows (Fig. 6). The measured rates of $\mathrm{CO}_{2}$ release from chamber deployments with A. marina pneumatophores in pristine and contaminated cells were 17-5.7 times higher, respectively, than across the bare sediment surface $(p<0.001)$. $\mathrm{CO}_{2}$ emission in deployments with burrows was increased 5.6 in 
non-contaminated sediment $(p<0.01)$ and 2.9 in contaminated sediment $(p<0.001)$. It is important to note, however, that the number of pneumatophores and burrows trapped inside the measuring chamber ( 1 burrow equivalent to $200 \mathrm{~m}^{-2}$ and 3 pneumatophores equivalent to $600 \mathrm{~m}^{-2}$ ) was much higher than the abundance of biogenic structures in the cells (Table 2).

The estimated $\mathrm{CO}_{2}$ emission per pneumatophore was similar in pristine $\left(0.27 \pm 0.08 \mathrm{mmol}\right.$ pneum. $\left.{ }^{-1} \mathrm{day}^{-1}\right)$ and contaminated sediment $\left(0.38 \pm 0.11 \mathrm{mmol}\right.$ pneum. ${ }^{-1}$ day $\left.^{-1}\right)$. By multiplying with the average pneumatophore density observed in each treatment (Table 2), we obtain an estimate for the increase in $\mathrm{CO}_{2}$ emission due to pneumatophores of 4.1 (29\%) and $9.5 \mathrm{mmol} \mathrm{m}^{-2} \mathrm{~d}^{-1}(15 \%)$ in non-contaminated and contaminated cells, respectively. The average $\mathrm{CO}_{2}$ emissions from individual crab burrows (including animal respiration) were within the same range than from single pneumatophores at non-contaminated and contaminated conditions $\left(0.23 \pm 0.11\right.$ and $0.51 \pm 0.10 \mathrm{mmol} \mathrm{m}^{-2} \mathrm{~d}^{-1}$, respectively). Most burrows contained one crab, but this could not be documented since crabs rapidly retreated to their burrows when disturbed. No attempts were made to recover the inhabitants, but in many cases, they were visible in the burrow opening. We therefore

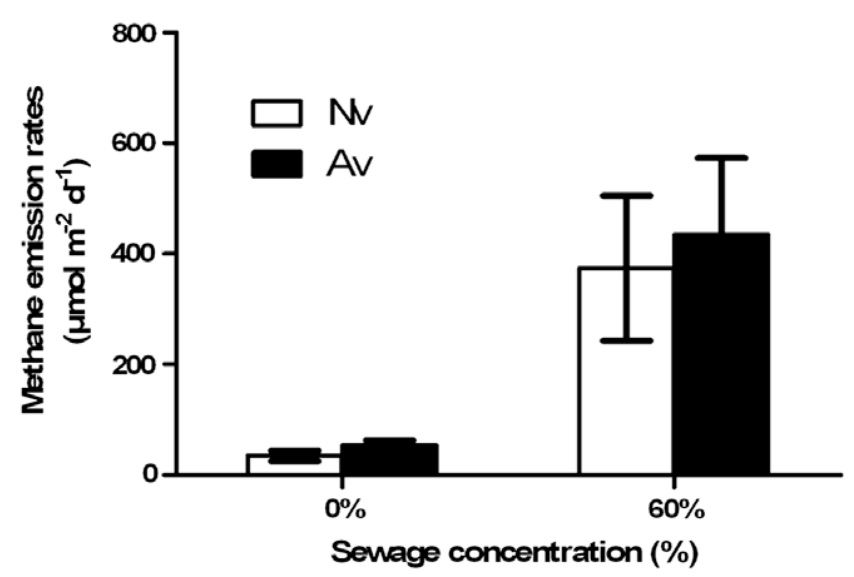

Fig. 5. Emission of $\mathrm{CH}_{4}$ from unvegetated ( $\mathrm{Nv}$ - open bars) and Avicennia marina vegetated (Av - solid bars) sediment exposed to 0 and $60 \%$ sewage loading in the dark for March 2007. Values are given as mean $\pm \operatorname{SE}(n=3)$.

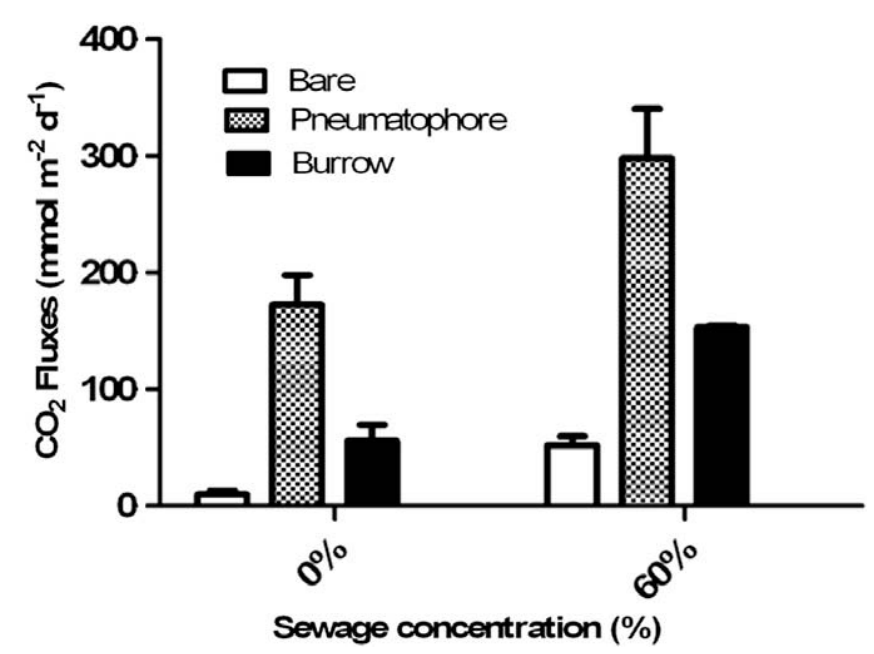

Fig. 6. Dark emission of $\mathrm{CO}_{2}$ from air-exposed sediment in unvegetated and Avicennia marina vegetated sediment exposed to 0 and $60 \%$ sewage loading during March 2007. Rates are shown for sediment with 600 Avicennia marina pneumatophores $\mathrm{m}^{-2}$ and sediment with $200 \mathrm{crab}$ burrows $\mathrm{m}^{-2}$. Values are given as mean \pm SE $(n=3-6)$. must rely on the estimate of Skov et al. (2002) that $81 \%$ of all burrows were inhabited. Part of the excess $\mathrm{CO}_{2}$ emission from burrows must therefore originate from crab respiration.

Since crabs inhabiting the sampled burrows were not identified, but average $\mathrm{CO}_{2}$-production by crabs was described by a power function regardless of crab species and sex (Fig. 7 - upper). Thus, when using the average weight of all sampled crabs (1.1 g wet wt) $\mathrm{CO}_{2}$-production by crabs was $0.16 \mathrm{mmol} \mathrm{CO}_{2}$ ind. ${ }^{-1} \mathrm{~d}^{-1}$. Taking into consideration the crab respiration inside the burrow and corrected (subtract) for RSP from a surface area corresponding to the burrow opening, $\mathrm{CO}_{2}$ emissions per burrow increased $(p<0.001)$ from $0.08 \pm 0.07 \mathrm{mmol}^{\text {burrow }}{ }^{-1}$ day $^{-1}$ to $0.39 \pm 0.01 \mathrm{mmol}$ burrow $^{-1}$ day $^{-1}$ in non-contaminated and contaminated cells, respectively. Multiplying these values by the average burrow density in each treatment (Table 2), the area-specific burrow wall respiration increased $(p<0.05)$ from $68.7 \pm 57.7 \mathrm{mmol} \mathrm{m}^{-2}$ day $^{-1}$ in non-contaminated to $312.5 \pm 28.2 \mathrm{mmol} \mathrm{m}^{-2}$ day $^{-1}$ in contaminated mesocosms. Dividing the burrow $\mathrm{CO}_{2}$ release by the amount of gas released by an area of exposed sediment equivalent to the area of the burrow opening (BOA), a ratio of 44 is obtained at non-contaminated conditions. However, since the burrow total surface area (BTSA) is only 21 times larger than the BOA, the area-specific burrow wall $\mathrm{CO}_{2}$ release appears 2.1 times greater than that of the surface sediment. In contaminated sediments the corresponding $\mathrm{CO}_{2}$ flux ratio is 56, resulting in 2.7 times increased area-specific $\mathrm{CO}_{2}$ release in the burrow lumen.

Terebralia palustris respiration also followed a power function when related to body weight (Fig. 6 - Lower). The average T. palus-
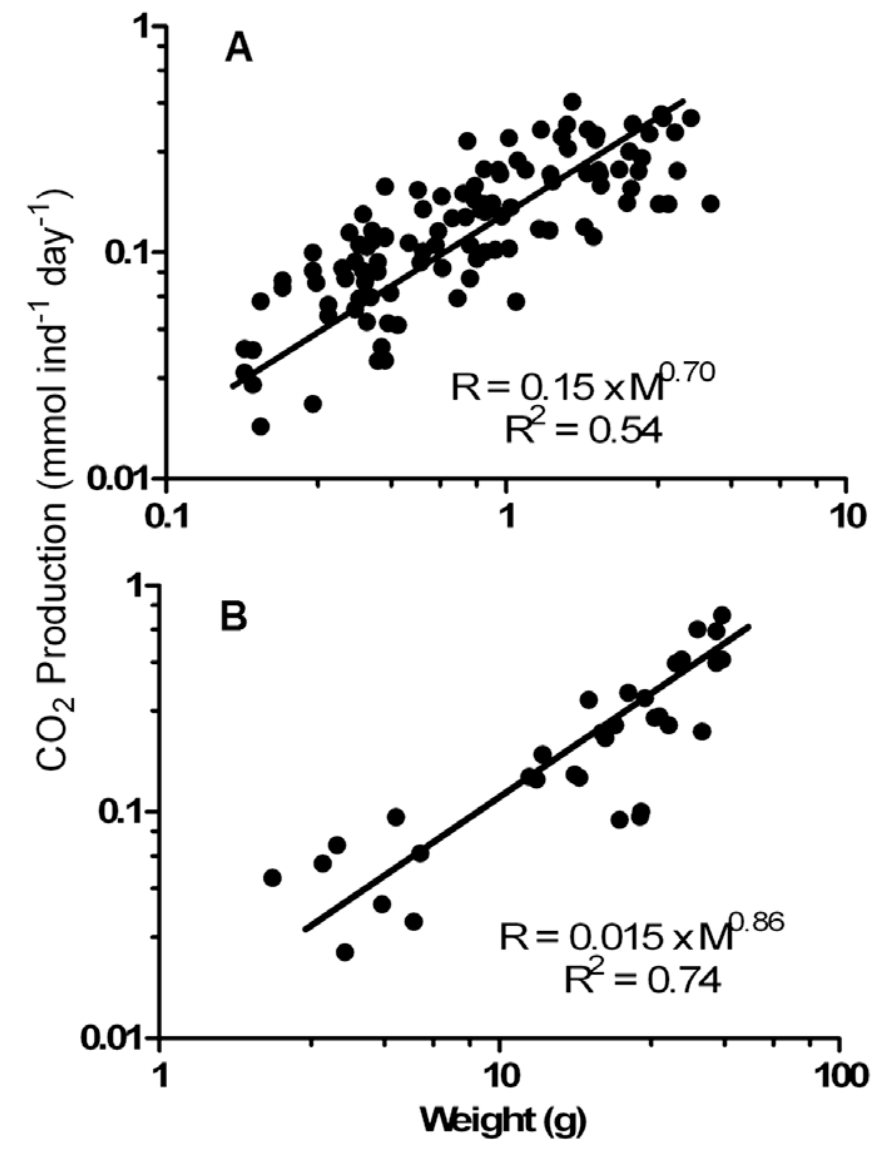

Fig. 7. Respiratory $\mathrm{CO}_{2}$ production ( $R$ ) by: (A) individual fiddler crabs (Uca spp.) and (B) Terebralia palustris as a function of live body weight $(M)$. Values are given as mean $\pm \operatorname{SE}(n=100$ sequential $10 \mathrm{~s}$ measuring intervals). The fiddler crab data contains males and females. The regression equation is given. 
tris individual (22 g wet wt) therefore respired $0.24 \mathrm{mmol} \mathrm{CO}_{2}$ ind. ${ }^{-1} \mathrm{~d}^{-1}$. Thus when applying the abundance of $T$. Palustris in the mesocosm cells $\left(4 \mathrm{~m}^{-2}\right), 0.97 \mathrm{mmol} \mathrm{m}^{-2} \mathrm{~d}^{-1} \mathrm{CO}_{2}$ production is attributable to gastropods.

The role of the different compartments for $\mathrm{CO}_{2}$ emission in airexposed sediment during dark incubations, suggested that the bare sediment surface was responsible for $>70 \%$ of $\mathrm{CO}_{2}$ release in contaminated cells and $<60 \%$ in non-contaminated cells (Table 4 ). Thus fauna and crab burrows accounted for up to $40 \%$ of the $\mathrm{CO}_{2}$ release in unvegetated cells, whereas pneumatophores increased the importance of biogenic structures for $\mathrm{CO}_{2}$ emissions by 13 and $16 \%$ in planted non-contaminated and contaminated cells, respectively.

\section{Discussion}

\subsection{Carbon fluxes}

The exchange of $\mathrm{TCO}_{2}$ across mangrove sediment surfaces devoid of biogenic structures represents the net outcome of near surface heterotrophic carbon mineralization and carbon fixation by microphytobenthic primary producers (Kristensen and Alongi, 2006). Benthic respiration (RSP) are comparable to the global average of $61 \pm 46 \mathrm{mmol} \mathrm{m}^{-2} \mathrm{~d}^{-1}$ found for mangrove sediments (Bouillon et al., 2008b). While sewage amendment and immersion/emersion periods clearly affected RSP in our mesocosm system, there was no apparent effect of vegetation on benthic RSP. Even though the saplings of $A$. marina grew well during the 12 month period since February 06, their biomass was apparently insufficient to significantly affect microbial pathways and organic matter dynamics. This way the results obtained here from vegetated cells should therefore be considered with care with respect to the effects of vegetation, especially when trying to extrapolate to mature constructed wetlands and forests.

Alongi (2009) noted higher average $\mathrm{CO}_{2}$ efflux when mangrove sediment are exposed to the atmosphere $(69 \pm 8 \mathrm{mmol}$ $\mathrm{CO}_{2} \mathrm{~m}^{-2} \mathrm{~d}^{-1}$ ) than when they are immersed by tides ( $49 \pm 6 \mathrm{mmol}$ $\mathrm{CO}_{2} \mathrm{~m}^{-2} \mathrm{~d}^{-1}$ ), which may be explained by the combination of higher sediment temperatures during emersion, faster molecular diffusion in gases than fluids and increased surface area for aerobic respiration and chemical oxidation. In contrast, we found a tendency towards a $\sim 2$ times faster $\mathrm{CO}_{2}$-efflux during immersion than emersion, which could be explained by the higher amount of dissolved labile organic matter (secondary treatment or seawater) available for decomposition when mesocosms were inundated with seawater-sewage mixture.

The consistently 2-4 times higher near-surface microheterotrophic activity observed in contaminated than non-contaminated

\section{Table 4}

$\mathrm{CO}_{2}$ emission budget in the dark during emersion for both unvegetated and Avicennia marina planted sediment exposed to 0 and 60\% sewage during March and April of 2007. Rates are partitioned into the contribution of bare sediment, pneumatophores, burrows, crabs and gastropods. Terebralia palustris respiration is based on an average animal size of $22 \mathrm{~g}\left(0.24 \mathrm{mmol} \mathrm{CO}_{2}\right.$ ind.$\left.^{-1} \mathrm{~d}^{-1}\right)$, while crab respiration is based on an average size of $1.1 \mathrm{~g}\left(0.16 \mathrm{mmol} \mathrm{CO}_{2}\right.$ ind. $\left.{ }^{-1} \mathrm{~d}^{-1}\right)$. It is assumed that 0.81 crabs were present inside each burrow. Rates are given as mean $\pm \mathrm{SE}\left(\mathrm{mmol} \mathrm{m}^{-2} \mathrm{~d}^{-1}\right)$. Numbers in parenthesis are the\% contribution of each component; n.a.: not applicable.

\begin{tabular}{lcllll}
\hline & \multicolumn{2}{c}{ Unvegetated } & & Vegetated \\
\cline { 2 - 3 } \cline { 5 - 6 } & $0 \%$ & $60 \%$ & & $0 \%$ & $60 \%$ \\
\hline Bare sediment & $6 \pm 1(60)$ & $62 \pm 14(94)$ & & $14 \pm 6(47)$ & $42 \pm 3(70)$ \\
Pneumatophores & n.a. & n.a. & & $4 \pm 1(13)$ & $10 \pm 1(16)$ \\
Burrows & $1 \pm 1(10)$ & $1 \pm 1(1.5)$ & & $8 \pm 2(27)$ & $5 \pm 1(9)$ \\
Crabs & $2 \pm 0(20)$ & $2 \pm 0(3)$ & & $3 \pm 0(10)$ & $2 \pm 0(3)$ \\
Gastropods & $1 \pm 0(10)$ & $1 \pm 0(1.5)$ & & $1 \pm 0(3)$ & $1 \pm 0(2)$ \\
Total & $10 \pm 1$ & $66 \pm 14$ & & $30 \pm 6$ & $60 \pm 3$ \\
\hline
\end{tabular}

Table 5

Depth integrated $(0-14 \mathrm{~cm})$ total anaerobic $\mathrm{CO}_{2}$ production $\left(\mathrm{mmol} \mathrm{m}^{-2} \mathrm{~d}^{-1}\right)$ in jarexperiments as well as depth integrated $\mathrm{FeR}$ and SRR based $\mathrm{CO}_{2}$ production during March 2007. "Other" represents unaccounted $\mathrm{CO}_{2}$ from jars, which supposedly is aerobic respiration. Values represent a $24 \mathrm{~h}$ cycle emission (emersion/immersion during dark period). Numbers in parenthesis indicate percent contribution to total $\mathrm{CO}_{2}$ production (for integrated calculations average values from 4-6 accounted for 4$7 \mathrm{~cm}, 8-10$ for $7-11 \mathrm{~cm}$, and $12-14$ for $11-14 \mathrm{~cm}$ depth).

\begin{tabular}{llllll}
\hline Process & \multicolumn{2}{l}{ Unvegetated } & & \multicolumn{2}{l}{ Vegetated } \\
\cline { 2 - 3 } \cline { 5 - 6 } & $0 \%$ & $60 \%$ & & $0 \%$ & $60 \%$ \\
\hline Total jar $\mathrm{CO}_{2}$ prod & 44 & 89 & & 72 & 97 \\
$\mathrm{FeR} \mathrm{CO}_{2}$ prod & $25(57)$ & $18(20)$ & & $13(18)$ & $7(7)$ \\
$\mathrm{SRR} \mathrm{CO}_{2}$ prod & $5(11)$ & $26(29)$ & & $5(7)$ & $18(19)$ \\
Other (aerobic!?) & $13(30)$ & $47(53)$ & & $54(75)$ & $69(71)$ \\
$\mathrm{CO}_{2}$ flux & 31 & 167 & & 48 & 103 \\
$\mathrm{CO}_{2}$ jar $/ \mathrm{CO}_{2}$ flux & 1.41 & 0.53 & & 1.5 & 0.94 \\
\hline
\end{tabular}

cells, as indicated by higher $\mathrm{CO}_{2}$ release in the dark during both immersion and emersion (Fig. 4), is caused by the regular amendment with organic matter and subsequent stimulation of microbial heterotrophic activity in these cells. Other aquatic systems subjected to massive and continuous organic loading, such as natural sediments contaminated by fish farming (Holmer and Kristensen, 1992; Holmer and Heilskov, 2008) and constructed laboratory systems (Valdemarsen et al., 2009; Valdemarsen et al., in press), show similar dramatic increases in mineralization rates (2-10 times). In this experiment, where organic matter content was similar in noncontaminated and contaminated mesocosms, it therefore appears that excess benthic metabolism in amended mesocosms is primarily driven by organic/nutrient input as opposed to indigenous organic matter. Furthermore, the lack of C-accumulation in sewage amended mesocosms indicate that sewage derived organic carbon was either totally or partially mineralized during immersion, or lost from system when the water phase was flushed during emersion periods. Also, the organic matter deposited or infiltrated in the sediment seems also to be rapidly mineralize hampering its accumulation in the sediment, as observed in previous studies (Valdemarsen et al., 2009).

Stimulated nutrient driven benthic primary production during immersion also contributed significantly to the C-loading in contaminated cells, with values 10 times higher than at pristine conditions, although benthic Chl $a$ concentration was only 2-3 times higher. The lower primary productivity at inundated pristine mesocosms as well as during emersion period at both sewage concentrations is probably caused by deficiency/exhaustion of nutrients and/or photoinhibition and dessication (Blanchard et al., 2001; Consalvey et al., 2004). We have no explanation for the surprising lack of NPP in contaminated planted cells during emersion, except for unknown methodological faults or coincidental selection of sites poor in microphytobenthos (Colijn and Dejonge, 1984). In any case, GPP was 4.3-6.7 times higher in contaminated than non-contaminated mesocosm cells. A similar difference was found between an anthropogenically contaminated (Mtoni) and a pristine (Ras Dege) mangrove forest in Tanzania (Kristensen et al., 2008b).

Methane emission from sediment to the atmosphere in our non-contaminated mesocosms was hardly detectable, as observed for most pristine natural mangrove areas (Alongi 2009). The higher nutrient and organic loading in contaminated cells stimulated methane emissions 8-10 times, which is similar to other organic enriched mangrove sediments during oxygen depletion (Purvaja and Ramesh, 2001; Hegde et al., 2003; Alongi et al., 2005). However, since $\mathrm{CH}_{4}$ emissions were 2-3 orders of magnitude lower than $\mathrm{CO}_{2}$ emissions in our system, they contribute insignificantly to carbon budgets in sewage amended mesocosms (see below). 


\subsection{The role of biogenic structures}

When measuring $\mathrm{CO}_{2}$ exchange across the sediment-air interface at bare sites, measured rates may be underestimates due to the exclusion of biogenic structures (pneumatophores and crab burrows) (see Kristensen et al., 2008a). Transport of gases is then largely limited to diffusion across the horizontal sedimentwater/air interface. This deficit is most pronounced during emersion when gas exchange from deep sediment is enhanced through open lenticels of pneumatophores (Allaway et al., 2001) and unplugged fiddler crab burrows (De la Iglesia et al., 1994). Under contaminated conditions, the effect of biogenic structures on $\mathrm{CO}_{2}$ emissions is decreased due to the high carbon mineralization at the sediment surface (Table 6). In this experiment, pneumatophores increases (13-16\%) $\mathrm{CO}_{2}$ emission from air-exposed sediment during darkness (Table 4 ), but we cannot partition the relative contribution of root respiration (Kitaya et al., 2002) and $\mathrm{CO}_{2}$ derived from heterotrophic $\mathrm{CO}_{2}$ production in deep sediments (Scholander et al., 1955). Thus, our methods may overestimate the importance of pneumatophores for $\mathrm{CO}_{2}$ exchange between sediment and air in exposed sediments. However, estimated $\mathrm{CO}_{2}$ emission from A. marina pneumatophores in pristine and contaminated cells $\left(0.27-0.38 \mathrm{mmol} \mathrm{d}^{-1}\right)$ was comparable to rates found by Kristensen et al. (2008b) for pristine and anthropogenic contaminated mangroves in Tanzania, as well as for $50 \%$ taller pneumatophores measured in Japan by Kitaya et al. (2002).

Diffusive $\mathrm{CO}_{2}$ transport from crab burrows to the atmosphere originates from carbon mineralization in the deep sediments that diffuses through the burrow walls (Pinder and Smits, 1993; Datta, 2005) as well as crab respiration. The contribution from burrows is augmented due to the large surface area of burrow walls and enhanced decomposition within the burrow lining (e.g., Botto et al., 2006). These processes not only occur during emersion, but also during immersion when fiddler crab burrows are plugged. Consequently $\mathrm{CO}_{2}$ must accumulate inside inundated burrows, causing a burst of $\mathrm{CO}_{2}$ emission once the crab burrows are opened, but this process is unknown and should be considered. In contrast to root respiration, crab and burrow respiration is an integrated part of C-budgets as they reflect heterotrophic $\mathrm{CO}_{2}$ production (Kristensen and Alongi 2006). Although, crab burrows occurred in low abundance in this experiment, they may contributed significantly (2$27 \%$ ) to the total $\mathrm{CO}_{2}$ emission (Table 4). The total impact of crabs was, as for pneumatophores, most pronounced under non-contaminated conditions when overall sediment metabolism was low. Similar results were obtained in sediments colonized by Alpheus macellarius in pristine and organic enriched (fish farm wastes) sediments (Holmer and Heilskov, 2008). The $\mathrm{CO}_{2}$ emission rates from single burrows are within the range reported in Kristensen et al. (2008b) in Tanzanian for ocypodid or grapsid mangrove crabs (0.2-0.5 mmol bur. $\left.{ }^{-1} \mathrm{~d}^{-1}\right)$. However, the presence of sewage increased $\mathrm{CO}_{2}$ emission from individual burrows by a factor of 5 times due to stimulated activity along the burrow walls of microbial communities known to inhabit these systems (Kristensen et al., 2005). However, the area-specific $\mathrm{CO}_{2}$ emission by burrow walls was 2-3 times larger when compared with sediment surface under both pristine and contaminated situations. Higher burrow emission values are expected if other mangrove crabs are present, such as sesarmids, known to have much larger burrows (Berti et al., 2008).

\subsection{Carbon mineralization pathways}

Organic loading and biogenic structures also affected major pathways for organic $C$ mineralization between treatments and with depth in the sediments (Table 5). The high rates of anaerobic $\mathrm{CO}_{2}$ production in contaminated sediment are typical for environments with a continuous input of organic matter (Kristensen et al., 2000). However, there is no consistent depth pattern, which may be due to the low depth resolution, considering that the majority of the sewage organic matter as well as primary and secondary productivity are mineralized explicitly at the sediment surface. Also, is more likely that organic matter lability is independent of sediment depth and that the contamination signal reaches to more than $10 \mathrm{~cm}$ depth. Since only unvegetated sediment with $0 \%$ sewage showed a depth dependent decrease in $\mathrm{CO}_{2}$ production, tree roots in the vegetated sediment must drive high metabolic activity at depth through dissolved carbon exudation (Kristensen and Alongi, 2006). Rates of $\mathrm{CO}_{2}$ jar production in our mesocosms are within the lower range observed by Kristensen et al. (submitted for publication) for pristine and polluted mature mangroves.

Apart from aerobic respiration (OxR), all other major microbial pathways, such as $\mathrm{Fe}(\mathrm{III})$ reduction (FeR) and sulfate reduction (SRR) were quantified in this experiment, Since total anaerobic $\mathrm{CO}_{2}$ production by jar incubations is considered a measure of total carbon oxidation (TACP), carbon oxidation by aerobic respiration should in principle be: $\mathrm{OxR}=\mathrm{TACP}-\mathrm{FeR} / 4-2 \mathrm{SRR}$, where FeR and SRR are converted to carbon units using standard stoichiometries (Canfield et al., 2005). However, total anaerobic $\mathrm{CO}_{2}$ production in jars was much higher than the sum of SRR and FeR, mainly in vegetated mesocosms (Table 5 ). This must be due to importance of other respiration pathways not quantified in jarexperiments. However, while denitrification showed to be minor in the present study, manganese and methanogenesis have traditionally been considered unimportant in mangrove sediments

Table 6

Calculation overview of daily ( $24 \mathrm{~h}$ ) total system carbon gas emission budgets. The table is separated into measured input parameters and calculated budget components. Basic assumptions: (a) $1 \mathrm{~d}$ has $12 \mathrm{~h}$ light and $12 \mathrm{~h}$ dark periods; (b) sediment is covered by water (immersion period) during half of each $12 \mathrm{~h}$ period; (c) abundance of pneumatophores (pneum.) and crab burrows is equal to a crude median of all examined cells (Table 2): 20 and $16 \mathrm{~m}^{-2}$, respectively; (d) burrows contain on average $0.81 \mathrm{crab}$ inhabitants (Skov et al., 2002). Input parameter: time = time of day; budget component: time = timing per day.

\begin{tabular}{|c|c|c|c|c|c|c|}
\hline & Acronym & Calculation/upscaling & Unit & Time & Tidal level & Data location \\
\hline \multicolumn{7}{|l|}{ Input parameters } \\
\hline Sediment emission (immersion) & Se-im & Measured & $\mathrm{mmol} \mathrm{m}^{-2} \mathrm{~h}^{-1}$ & Light/dark & Immersion & Fig. 3 \\
\hline Sediment emission (emersion) & Se-em & Measured & $\mathrm{mmol} \mathrm{m}^{-2} \mathrm{~h}^{-1}$ & Light/dark & Emersion & Fig. 4 \\
\hline Sediment emission $(\mathrm{em})+3$ pneum. & PSe & Measured & $\mathrm{mmol} \mathrm{m}^{-2} \mathrm{~h}^{-1}$ & Light/dark & Immersion & Fig. 5 \\
\hline Sediment emission $(\mathrm{em})+1$ burrow & $\mathrm{PBe}$ & Measured & $\mathrm{mmol} \mathrm{m}^{-2} \mathrm{~h}^{-1}$ & Light & Immersion & Fig. 5 \\
\hline Pneumatophore emission & $\mathrm{Pe}$ & $(\mathrm{PSe}-\mathrm{Se}-\mathrm{em}) / 3$ & $\mathrm{mmol} \mathrm{m}^{-2} \mathrm{~h}^{-1}$ & Dark & Immersion & Text \\
\hline Total burrow emission & TBe & PBe-Se-em & $\mathrm{mmol} \mathrm{m}^{-2} \mathrm{~h}^{-1}$ & Dark & Immersion & Text \\
\hline Crab emission & $\mathrm{Ce}$ & Measured & $\mathrm{mmol} \mathrm{m}^{-2} \mathrm{~h}^{-1}$ & Dark & Immersion & Text \\
\hline Burrow emission & $\mathrm{Be}$ & TBe-0.81Ce & $\mathrm{mmol} \mathrm{m}^{-2} \mathrm{~h}^{-1}$ & Dark & Immersion & Text \\
\hline \multicolumn{7}{|l|}{ Budget component } \\
\hline Sediment (im) & DSe (im) & $\mathrm{Se} \times 9 \mathrm{~m}^{-2}$ & $\operatorname{mmol} 12^{-1}$ & $6 \mathrm{~h}$ light $+6 \mathrm{~h}$ dark & Immersion & \\
\hline Sediment $(\mathrm{em})+\mathrm{Be}$ & DSe (em) & $\left(\mathrm{Se}+0.5^{*} 16 \mathrm{Be}\right) \times 9 \mathrm{~m}^{-2}$ & $\operatorname{mmol} 12^{-1}$ & 6 h light +6 h dark & Emersion & \\
\hline Sediment $(\mathrm{em})+\mathrm{Be}+\mathrm{Pe}$ & DSe (em) & $(\mathrm{Se}+20 \mathrm{Pe}+0.516 \mathrm{Be}) \times 9 \mathrm{~m}^{-2}$ & $\operatorname{mmol} 12^{-1}$ & 6 h light +6 h dark & Emersion & \\
\hline
\end{tabular}


(Kristensen et al., 2008a; Alongi, 2009), leading us to consider that in situ these discrepancies could be due aerobic respiration (Table 5). Although these rates must be overestimated, although no good explanations can be given at the present moment. it has been shown that aerobic respiration is considered one of the most important respiration processes with a share of $40-50 \%$ (see review by Kristensen et al., 2008a).

FeR was substituted by SRR in contaminated sediment due to the almost complete absence of Fe(III) (Fig. 1 and 2). Thus, SRR increased particularly in the upper $5 \mathrm{~cm}$ of contaminated cells, as observed in other sediments where labile organic matter is continuously supplied to the sediment surface (Valdemarsen et al., 2009). Pneumatophores appeared to increase OxR by stimulating $\mathrm{O}_{2}$ diffusion, via the roots, into otherwise anoxic sediment (Table 5). This process appears crucial for maintaining $\mathrm{Fe}(\mathrm{III})$ for FeR, especially in vegetated non-contaminated cells (Fig. 1). Roots may also stimulate heterotrophic processes by excreting labile organic exudates into the surrounding sediment (Andersen and Kristensen, 1988; Aller, 1994; Kristensen, 2000; Kristensen and Alongi, 2006), and this process may explain the slightly higher mineralization rates observed at depth in vegetated non-contaminated sediment when compared to bare non-vegetated sediment.

The ratio of total anaerobic $\mathrm{CO}_{2}$ production $(14 \mathrm{~cm}$ depth integrated) and gas emission from sediments during a $24 \mathrm{~h}$ cycle was 1.5 in non-contaminated cells (Table 5), which might indicate $\mathrm{CO}_{2}$ consumption during authigenic mineral formation and losses via chemotrophy by sulfide oxidizers (Bouillon et al., 2008a; Kristensen et al., 2008a), or $\mathrm{CO}_{2}$ is being released and not measured (e.g., burst $\mathrm{CO}_{2}$ from crab burrows). For unvegetated contaminated sediments, the ratio is $<1$, indicating that $\mathrm{CO}_{2}$ production via SRR must occur below $14 \mathrm{~cm}$ sediment depth (Alongi et al., 2005).

Denitrification in mangrove ecosystems is primarily regulated by nitrate availability, temperature, salinity and organic matter availability (Alongi, 2009). The rates obtained in our non-contaminated experimental cells are within the low range (27$470 \mu \mathrm{mol} \mathrm{m}{ }^{-2} \mathrm{~d}^{-1}$ ) of the ones found in East African (e.g., Kristensen et al., submitted for publication) and Thailand mangroves (Kristensen et al., 1998). The high rates obtained in contaminated sediment must be driven by high ammonium availability and consequently coupled nitrification-denitrification and increased $\mathrm{O}_{2}$ availability due to high benthic NPP (Canfield et al., 2005). Other studies have also recorded high denitrification at rates of more than $15000 \mu \mathrm{mol} \mathrm{m}^{-2} \mathrm{~d}^{-1}$ in contaminated mangrove sediments (Corredor and Morell, 1994; Rivera-Monroy et al., 1999), and it has been proposed that high denitrification rates in contaminated mangroves is governed by increased $\mathrm{N}$-availability and higher nutrient driven $\mathrm{O}_{2}$ production by benthic microalgae (e.g., Risgaard-Petersen et al., 1994). The present data confirm the potential of mangrove sediments for nitrate depuration of secondary sewage as suggested by Corredor and Morell (1994).

\subsection{Wetland functioning and environmental implications}

Estimates of total inorganic carbon in the different mangrove mesocosms can be provided by taking into consideration the contribution by various mangrove compartments (Table 6). The estimated total $\mathrm{CO}_{2}$ emission to the atmosphere in the mangrove mesocosms in March 2007 showed that more than 50\% is in most cases released from the sediment during emersion periods, especially in vegetated cells where pneumatophores are present (Table 7). Fauna and biogenic structures accounted for up to $60 \%$ of the total $\mathrm{CO}_{2}$ emission in non-contaminated mesocosms, increasing by 2-3 times the global average found for mangrove sediments (Bouillon et al., 2008b), while the corresponding contribution in contaminated cells was always below $30 \%$ (Table 4). The role of fauna in organic matter degradation is known to decrease in
Table 7

Total emission of $\mathrm{CO}_{2}\left(\mathrm{mmol} 12 \mathrm{~h}^{-1}\right)$ to the atmosphere in: (A) the mangrove mesocosms at both immersion and emersion periods and different vegetation and sewage conditions. The emissions at the unvegetated plots are assumed to be devoid of pneumatophores but not burrows. At plots conditions, burrows and pneumatophores density are shown in Table 2; and (B) natural conditions (300 burrows $\mathrm{m}^{-2}$ and 70 pneumatophores $\mathrm{m}^{-2}$ are considered). See Table 6 for further explanation. The rates were calculated for $12 \mathrm{~h}$ low tides and $12 \mathrm{~h}$ high tides $\mathrm{d}^{-1}$. Error values are SE.

\begin{tabular}{llrrr}
\hline & $\%$ & \multicolumn{1}{l}{$\begin{array}{l}\text { Immersion } \\
\mathrm{CO}_{2}\end{array}$} & \multicolumn{1}{l}{$\begin{array}{l}\text { Emersion } \mathrm{CO}_{2} \\
\text { (plots) }\end{array}$} & \multicolumn{1}{l}{$\begin{array}{l}\text { Total } \mathrm{CO}_{2} \\
\text { (plots) }\end{array}$} \\
\hline A & & & & \\
Unvegetated & 0 & $87.3 \pm 14$ & $27.9 \pm 16.1$ & $115.2 \pm 21.0$ \\
Vegetated & 60 & $164.0 \pm 13.0$ & $146.5 \pm 15.6$ & $310.5 \pm 20.3$ \\
& 0 & $72.9 \pm 13.0$ & $93.4 \pm 15.6$ & $166.3 \pm 20.3$ \\
$B$ & 60 & $-399.6 \pm 13.0$ & $250.2 \pm 15.6$ & $-149.4 \pm 20.3$ \\
Unvegetated & 0 & $87.3 \pm 14$ & $79.8 \pm 16.1$ & $167.1 \pm 21.0$ \\
Vegetated & 60 & $164.0 \pm 13.0$ & $197.0 \pm 15.6$ & $361.0 \pm 20.3$ \\
& 0 & $72.9 \pm 13.0$ & $406.1 \pm 15.6$ & $479.0 \pm 20.3$ \\
& 60 & $-399.6 \pm 13.0$ & $610.4 \pm 15.6$ & $210.8 \pm 20.3$ \\
\hline
\end{tabular}

anthropogenic contaminated situations, such as in sediments bellow fish farms (Holmer and Heilskov, 2008). However, the biogenic contributions in our mesocosms must be lower than in mature wetlands, where mangrove trees are typically larger with more well developed pneumatophores (e.g., Dahdouh-Guebas et al., 2007) and the abundance and diversity of crabs is much higher (Hartnoll et al., 2002; Skov et al., 2002). For instance, if the density of biogenic structures is raised to a level corresponding to that commonly observed in mature mangrove environments (e.g., 300 burrows $\mathrm{m}^{-2}$ and 70 pneumatophores $\mathrm{m}^{-2}$, at Kristensen et al., 2008b) the $\mathrm{CO}_{2}$ emissions during emersion increase considerably (when compared with mesocosms conditions) by $16 \%$ up to $180 \%$ for unvegetated and vegetated conditions, respectively, by increasing OM decay rate and consequently decrease OM sediment pool (Kristensen, 2000).

A higher abundance of biogenic structures (roots, pneumatophores and burrows) will also have profound effects on sediment biogeochemistry through simultaneously enhanced translocation of oxygen and organic matter to deep sediment layers. As a consequence, both FeR and SRR may be stimulated by organic enrichment (Alongi, 1998), and whereas FeR may dominate Cmineralization at low to intermediate organic loading, SRR is typically the dominating mineralization pathway in heavily contaminated sediments. Below a certain maximum metabolic threshold, accumulation of generated sulfides may be hampered by continuous $\mathrm{O}_{2}$-driven reoxidation processes and precipitation of Fe-sulfides (Valdemarsen et al., 2009). Conversely, if the maximum metabolic threshold is exceeded and Fe available for precipitation is depleted, free sulfide may accumulate with deleterious consequences for flora and fauna (Hargrave et al., 2008). This threshold was not exceeded in our mesocosm study and it is at present not known. The exact threshold value must depend on sediment properties (e.g., iron content and permeability), the type and age of the vegetation as well as the abundance of burrowing infauna. Although the organic loading rate in the present study was below the maximum metabolic threshold, the oxidation/reduction balance had shifted in favour of SRR, which in combination with the low salinity of discharged sewage also favoured methanogenesis as observed in Purvaja and Ramesh (2001). Furthermore, it appeared that the presence of pneumatophores and burrows facilitated $\mathrm{CH}_{4}$ transport and emission from the sediment to the atmosphere (Purvaja et al., 2004; Kristensen et al., 2008b), indicating that specific studies should address these processes to better understand the role biogenic structures in heavily contaminated ecosystems on greenhouse gas emissions. 
In conclusion, biogenic structures and bioturbation activities change sediment physical, chemical and biological structure and dynamics, leading not only to an increase in benthic mineralization but also to change the dominating microbial mineralization pathways. Our results confirm the importance of fauna and flora for the functioning of mangrove forests (Alongi, 2009) as well as their effective contribution to organic matter mineralization and nutrient cycling under organic-rich conditions (Canfield et al., 2005; Kristensen, 2008).

Furthermore, models on carbon dynamics in constructed wetlands exposed to sewage are strongly needed to improve our understanding of the system efficiency and metabolic threshold, including the reduction/oxidation processes involving sulfur and iron, as well as the role wetlands, including biogenic structures, for the emission of potential greenhouse gases $\left(\mathrm{CO}_{2}, \mathrm{CH}_{4}\right.$ and $\mathrm{N}_{2} \mathrm{O}$ ), and consequences for global warming.

\section{Acknowledgements}

The authors would like to thank Dr. K. Njau and Prof. Y. Mgaya and Prof. J. Machiwa for logistical support and Thomas Valdemarsen for commenting and correcting a previous version of this manuscript. We would also like to thank Fundação para a Ciência e a Tecnologia (scholarship SFRH/BD/25277/2005 for GPL). This study is part of the PUMPSEA (Peri-urban mangrove forests as filters and potential phytoremediators of domestic sewage in East Africa), contract number (INCO-CT2004-510863), funded by the 6th framework of the European Commission.

\section{References}

Allaway, W.G., Curran, M., Hollington, L.M., Ricketts, M.C., Skelton, N.J., 2001. Gas space and oxygen exchange in roots of Avicennia marina (Forssk.) Vierh. var. australasica (Walp.) Moldenke ex N.C. Duke, the grey mangrove. Wetl. Ecol. Manage. 9, 221-228.

Aller, R.C., 1994. Bioturbation and remineralization of sedimentary organic matter: effects of redox oscillation. Chem. Geol. 114, 331-345.

Alongi, D.M., 1998. The influence of stand age on benthic decomposition and recycling of organic matter in managed mangrove forests of Malaysia. J. Exp. Mar. Biol. Ecol. 225, 197-218.

Alongi, D.M., 2005. Mangrove-microbe-soil relations. In: Kristensen, E., Haese, R.R., Kostka, J.E. (Eds.), Macro- and Microorganisms in Marine Sediments. Coastal and Estuarine Studies, vol. 60. American Geophysical Union, Washington, pp. 85-104.

Alongi, D.M., 2009. The Energetics of Mangrove Forests. Springer Science. p. 216

Alongi, D.M., Pfitzner, J., Trott, L.A., Tirendi, F., Dixon, P., Klumpp, D.W., 2005. Rapid sediment accumulation and microbial mineralization in forests of the mangrove Kandelia candel in the Jiulongjiang Esturay, China. Estuar. Coast. Shelf. Sci., 605618.

Al-Sayed, H.A., Ghanem, E.H., Saleh, K.M., 2005. Bacterial community and some physico-chemical characteristics in a subtropical mangrove environment in Bahrain. Mar. Pollut. Bull. 50, 147-155

Andersen, F.Ø., Kristensen, E., 1988. Oxygen microgradients in the rhizosphere of the mangrove Avicennia marina. Mar. Ecol. Prog. Ser. 44, 201-204.

Berti, R., Cannicci, S., Fabbroni, S., Innocenti, G., 2008. Notes on the structure and the use of Neosarmatium meinerti and Cardisoma carnifex burrows in a Kenyan mangrove swamp (Decapoda Brachyura). Ethol. Ecol. Evol. 20, 101-113.

Blanchard, G.F., Guarini, J.M., Orvain, F., Sauriau, P.G., 2001. Dynamic behaviour of benthic microalgal biomass in intertidal mudflats. J. Exp. Mar. Biol. Ecol. 264, $85-100$.

Botto, F., Iribarne, O., Gutierrez, J., Bava, J., Gagliardini, A., Valiela, I., 2006. Ecological importance of passive deposition of organic matter into burrows of the SW Atlantic crab Chasmagnathus granulatus. Mar. Ecol. Prog. Ser. 312, 201-210.

Boudreau, B., 1998. Mean mixed depth of sediments: the wherefore and the why. Limnol. Oceanogr. 43, 524-526.

Bouillon, S., Connolly, R.M., Lee, S.Y., 2008a. Organic matter exchange and cycling in mangrove ecosystems: recent insights from stable isotope studies. J. Sea Res. 59, 44-58.

Bouillon, S., Borges, A.V., Castaneda-Moya, E., Diele, K., Dittmar, T., Duke, N.C., Kristensen, E., Lee, S.Y., Marchand, C., Middelburg, J.J., Rivera-Monroy, V.H., Smith, T.J., Twilley, R.R., 2008b. Mangrove production and carbon sinks: a revision of global budget estimates. Global Biogeochem. Cycles 22, 12.

Canfield, D.E., Kristensen, E., Thamdrup, B., 2005. Aquatic Geomicrobiology. Elsevier, Amsterdam.

Colijn, F., Dejonge, V.N., 1984. Primary production of microphytobenthos in the EMS-Dollard Estuary. Mar. Ecol. Prog. Ser. 14, 185-196.
Consalvey, M., Paterson, D.M., Underwood, G.J.C., 2004. The ups and downs of life in a benthic biofilm: migration of benthic diatoms. Diatom. Res. 19, 181-202.

Corredor, J.E., Morell, J.M., 1994. Nitrate depuration of secondary sewage effluents in mangrove sediments. Estuaries 17, 295-300.

Crites, R.W., Middlebrooks, E.J., Reed, S.C., 2006. Natural Wastewater Treatment Systems. CRC Press, FL, USA. p. 576.

Dahdouh-Guebas, F., Kairo, J.G., De Bondt, R., Koedam, N., 2007. Pneumatophore height and density in relation to micro-topography in the grey mangrove Avicennia marina. Belg. J. Bot. 140, 213-221.

Datta, M., 2005. Computer model for gas diffusion from nests of burrowing animals. Ethn. Dis. 15, 62-63.

De la Iglesia, H.O., Rodriguez, E.M., Dezi, R.E., 1994. Burrow plugging in the crab Uca uruguayensis and its synchronization with photoperiod and tides. Physiol. Behav. 55, 913-919.

Duarte, C.M., Middelburg, J.J., Caraco, N., 2005. Major role of marine vegetation on the oceanic carbon cycle. Biogeosciences 2, 1-8

PUMPSEA, 2008. Peri-urban mangrove forests as filters and potential phytoremediators of domestic sewage in East Africa. Final activity report. European Comission: FP6, INCO-CT2004-510863. Instituto de Ciências Aplicadas e Tecnologia, Lisbon, Portugal. p. 447.

Ferreira, T.O., Otero, X.L., Vidal-Torrado, P., Macías, F., 2007. Effects of bioturbation by root and crab activity on iron and sulfur biogeochemistry in mangrove substrate. Geoderma 142, 36-46.

Fossing, H., Jørgensen, B.B., 1989. Measurement of bacterial sulfate reduction in sediments - evaluation of a single-step chromium reduction method. Biogeochemistry 8, 205-222.

Gray, J.S., Wu, R.S.S., Ying, Y.O., 2002. Effects of hypoxia and organic enrichment on the coastal marine environment. Mar. Ecol. Prog. Ser. 238, 249-279.

Hall, P.O.J., Aller, R.C., 1992. Rapid, small-volume, flow injection analysis for $\mathrm{CO}_{2}$ and $\mathrm{NH}_{4}^{+}$in marine and freshwaters. Limnol. Oceanogr. 37, 1113-1119.

Hansen, K., Kristensen, E., 1998. The impact of the polychaete Nereis diversicolor and enrichment with macroalgal (Chaetomorpha linum) detritus on benthic metabolism and nutrient dynamics in organic-poor and organic-rich sediment. J. Exp. Mar. Biol. Ecol. 231, 201-223.

Hargrave, B.T, Holmer, M. Newcombe, C.P., 2008. Towards a classification of organic enrichment in marine sediments based on biogeochemical indicators. Mar. Pollut. Bull. 56, 810-824.

Hartnoll, R.G., Cannici, S., Emmerson, W.D., Fratini, S., Macia, A., Mgaya, Y., Porri, F., Ruwa, R.K., Shunula, J.P., Skov, M.W., Vannini, M., 2002. Geographic trends in mangrove crab abundance in East Africa. Wetl. Ecol. Manage. 10, 203-213.

Hegde, U., Chang, T.-C., Yang, S.-S., 2003. Methane and carbon dioxide emissions from Shan-Chu-Ku landfill site in northern Taiwan. Chemosphere 52, 12751285.

Heilskov, A.C., Holmer, M., 2001. Effects of benthic fauna on organic matter mineralization in fish-farm sediments: importance of size and abundance. ICES J. Mar. Sci. 58, 427-434.

Holmer, M., Heilskov, A.C., 2008. Distribution and bioturbation effects of the tropical alpheid shrimp Alpheus macellarius in sediments impacted by milkfish farming. Estuar. Coast. Shelf. Sci. 76, 657-667.

Holmer, M., Kristensen, E., 1992. Impact of marine fish cage farming on metabolism and sulfate reduction of underlying sediments. Mar. Ecol. Prog. Ser. 80, 191201.

Holmer, M., Kristensen, E., 1994a. Organic matter mineralization in an organic-rich sediment: experimental stimulation of sulfate reduction by fish food pellets. FEMS Microbiol. Ecol. 14, 33-44.

Holmer, M., Kristensen, E., 1994b. Co-existence of sulfate reduction and methane production in an organic rich sediment. Mar. Ecol. Prog. Ser. 107, 177-184.

Holmer, M., Andersen, F.Ø., Holmboe, N., Kristensen, E., Thongtham, N., 1999. Transformation and exchange processes in the Bangrong mangrove forest-seagrass bed system, Thailand. Seasonal and spatial variations in benthic metabolism and sulfur biogeochemistry. Aquat. Microb. Ecol. 20, 203-212.

Jørgensen, B.B., 1978. Comparison of methods for the quantification of bacterial sulfate reduction in coastal marine-sediments: 1 . Measurement with radiotracer techniques. Geomicrobiol. J. 1, 11-27.

Kitaya, Y., Yabuki, K., Kiyota, M., Tani, A., Hirano, T., Aiga, I., 2002. Gas exchange and oxygen concentration in pneumatophores and prop roots of four mangrove species. Trees Struct. Funct. 16, 155-158.

Kivaisi, A.K., 2001. The potential for constructed wetlands for wastewater treatment and reuse in developing countries: a review. Ecol. Eng. 16, 545-560.

Kristensen, E., 1988. Benthic fauna and biogeochemical processes in marine sediments: microbial activities and fluxes. In: Blackburn, T.H., Sørensen, J. (Eds.), Nitrogen Cycling in Coastal Marine Environments. John Wiley and Sons, Chichester, pp. 275-299.

Kristensen, E., 2000. Organic matter diagenesis at the oxic/anoxic interface in coastal marine sediments, with emphasis on the role of burrowing animals. Hydrobiologia 426, 1-24.

Kristensen, E., 2008. Mangrove crabs as ecosystem engineers; with emphasis on sediment processes. J. Sea Res. 59, 30-43.

Kristensen, E., Alongi, D.M., 2006. Control by fiddler crabs (Uca vocans) and plant roots (Avicennia marina) on carbon, iron, and sulfur biogeochemistry in mangrove sediment. Limnol. Oceanogr. 51, 1557-1571.

Kristensen, E., Jensen, M.H., Banta, G.T., Hansen, K., Holmer, M., King, G.M., 1998. Transformation and transport of inorganic nitrogen in sediments of a southeast Asian mangrove forest. Aquat. Microb. Ecol. 15, 165-175. 
Kristensen, E., Andersen, F.Ø., Holmboe, N., Holmer, M., Thongtham, N., 2000. Carbon and nitrogen mineralization in sediments of the Bangrong mangrove area, Phuket, Thailand. Aquat. Microb. Ecol. 22, 199-213.

Kristensen, E., Haese, R.R., Kostka, J.E., 2005. Interactions between Macro- and Microorganisms in Marine Sediments. American Geophysical Union, Washington, DC. p. 389

Kristensen, E., Bouillon, S., Dittmar, T., Marchand, C., 2008a. Organic carbon dynamics in mangrove ecosystems: a review. Aquat. Bot. 89, 201-219.

Kristensen, E., Flindt, M., Ulomi, S.A., Borges, A.V., Abril, G., Bouillon, S., 2008b. Emission of $\mathrm{CO}_{2}$ and $\mathrm{CH}_{4}$ to the atmosphere by sediments and open waters in two Tanzanian mangrove forests. Mar. Ecol. Prog. Ser. 370, 53-67.

Kristensen, E., Mangion, P., Tang, M., Flindt, M., Holmer, M., Ulomi, S.A., submitted for publication. Benthic metabolism and partitioning of electron acceptors for microbial carbon oxidation in sediments of two Tanzanian mangrove forests. Mar. Ecol. Prog. Ser.

Lorenzen, C.J., 1967. Determination of chlorophyll and phaeopigments: spectrophotometric equations. Limnol. Oceanogr. 12, 343-346.

Lyimo, T.J., Pol, A., Op den Camp, H.J.M., 2002. Sulfate reduction and methanogenesis in sediments of Mtoni mangrove forest, Tanzania. Ambio 31 614-616.

Nagelkerken, I., Blaber, S.J.M., Bouillon, S., Green, P., Haywood, M., Kirton, L.G., Meynecke, J.O., Pawlik, J., Penrose, H.M., Sasekumar, A., Somerfield, P.J., 2008 The habitat function of mangroves for terrestrial and marine fauna: a review. Aquat. Bot. 89, 155-185.

Nielsen, L.P., 1992. Denitrification in sediment determined from nitrogen isotope pairing. FEMS Microbiol. Ecol. 86, 357-362.

Nielsen, O.I., Kristensen, E., Macintosh, D.J., 2003. Impact of fiddler crabs (Uca spp.) on rates and pathways of benthic mineralization in deposited mangrove shrimp pond waste. J. Exp. Mar. Biol. Ecol 289, 59-81.

Penha-Lopes, G., Bartolini, F., Limbu, S., Cannicci, S., Paula, J., 2009. Are fiddler crabs potentially useful ecosystem engineers in mangrove wastewater wetlands? Mar. Pollut. Bull. 58, 1694-1703.

Penha-Lopes, G., Bartolini, F., Limbu, S., Cannicci, S., Mgaya, Y., Paula, J., in press. Ecosystem engineering potential of the gastropod Terebralia palustris (Linnaeus, 1767) in mangrove wastewater wetlands - a controlled mesocosm experiment. Environ. Pollut. Ser. A, Ecol. Biol.

Pinder, A.W., Smits, A.W., 1993. The burrow microhabitat of the land crab Cardissoma guanhumi - respiratory ionic conditions and physiological responses of the crabs to hypercapnia. Physiol. Zool. 66, 216-236.

Purnobasuki, H., Suzuki, M., 2004. Aerenchyma formation and porosity in root of a mangrove plant, Sonneratia alba (Lythraceae). J. Plant Res. 117, 465-472.

Purnobasuki, H., Suzuki, M., 2005. Aerenchyma tissue development and gaspathway structure in root of Avicennia marina (Forsk.) Vierh. J. Plant Res. 118 285-294.
Purvaja, R., Ramesh, R., 2001. Natural and anthropogenic methane emission from coastal wetlands of south India. Environ. Manage. 27, 547-557.

Purvaja, R., Ramesh, R., Frenzel, P., 2004. Plant-mediated methane emission from an Indian mangrove. Global Change Biol. 10, 1825-1834.

Risgaard-Petersen, N., Rysgaard, S., Nielsen, L.P., Revsbech, N.P., 1994. Diurnal variation of denitrification and nitrification in sediments colonized by benthic microphytes. Limnol. Oceanogr. 39, 573-579.

Rivera-Monroy, V.H., Twilley, R.R., 1996. The relative role of denitrification and immobilization in the fate of inorganic nitrogen in mangrove sediments (Terminos Lagoon, Mexico). Limnol. Oceanogr. 41, 284-296.

Rivera-Monroy, V.H., Torres, L.A., Nixon, B., Newmark, F., Twilley, R.R., 1999. The potential use of mangrove forests as nitrogen sinks of shrimp aquaculture pond effluents: the role of denitrification. J. World Aquacult. Soc. 30, 12-25.

Scholander, P.F., Dam, L.v., Scholander, S.I., 1955. Gas exchange in the roots of mangroves. Am. J. Bot. 42, 92-98.

Skov, M.W., Vannini, M., Shunula, J.P., Hartnoll, R.G., Cannicci, S., 2002. Quantifying the density of mangrove crabs: Ocypodidae and Grapsidae. Mar. Biol. 141, 725-732.

Stottmeister, U., Wießner, A., Kuschk, P., Kappelmeyer, U., Kästner, M., Bederski, O., Müller, R.A., Moormann, H., 2003. Effects of plants and microorganisms in constructed wetlands for wastewater treatment. Biotechnol. Adv. 22, 93-117.

Trimmer, M., Risgaard-Petersen, N., Nicholls, J.C., Engström, P., 2006. Direct measurement of anaerobic ammonium oxidation (anammox) and denitrification in intact sediment cores. Mar. Ecol. Prog. Ser. 326, 37-47.

Valdemarsen, T., Holmer, M., Kristensen, E., 2009. Metabolic threshold and sulfidebuffering in diffusion controlled marine sediments impacted by continuous organic enrichment. Biogeochemistry 95, 335-353.

Valdemarsen, T., Kristensen, E., Holmer, M., in press. S, C and N cycling in faunated marine sediments impacted by continuous organic enrichment. Mar. Ecol. Prog. Ser.

Wong, Y.S., Lan, C.Y., Chen, G.Z., Li, S.H., Chen, X.R., Liu, Z.P., Tam, N.F.Y., 1995. Effect of wastewater discharge on nutrient contamination of mangrove soils and plants. Hydrobiologia 295, 243-254.

Wong, Y.S., Tam, N.F.Y., Chen, G.Z., Ma, H., 1997. Response of Aegiceras corniculatum to synthetic sewage under simulated tidal conditions. Hydrobiologia 352, 8996.

Wu, Y., Tam, N.F.Y., Wong, M.H., 2008a. Effects of salinity on treatment of municipal wastewater by constructed mangrove wetland microcosms. Mar. Pollut. Bull. 57, 727-734.

Wu, Y., Chung, A., Tam, N.F.Y., Pi, N., Wong, M.H., 2008b. Constructed mangrove wetland as secondary treatment system for municipal wastewater. Ecol. Eng. 34, 137-146.

Yang, Q., Tam, N.F.Y., Wong, Y.S., Luan, T.G., Su, W.S., Lan, C.Y., Shin, P.K.S., Cheung, S.G., 2008. Potential use of mangroves as constructed wetland for municipal sewage treatment in Futian, Shenzhen. China Mar. Pollut. Bull. 57, 735-743. 